\title{
How to tell the story of change and transition of the energy, ecological and societal systems
}

\author{
Jean-Pierre Birat* \\ IF Steelman, 57280 Semécourt, France
}

Received: 27 September 2020 / Accepted: 6 January 2021

\begin{abstract}
After overusing the expression Sustainable Development, some action plan was needed to switch from rhetorical to transformational change. One of the answers was to propose the word Transition as a roadmap leading to the necessary level of change. A Transition is a passage from one stable regime to another, with a step that is neither instantaneous nor dangerous, like a Revolution, but is fast enough, anyway. The first Transition in the 2010s was the Energy Transition, i.e. a move towards less fossil fuels and more renewables. It started everywhere more or less at the same time, but Germany and its Energiewende was among the first contenders. The implicit objective was as much to control excessive anthropogenic GHG emissions as it was to possibly start a new period of growth based on green technologies. Very soon, however, the Fukushima disaster convinced Mrs. Merkel to change tack and veer towards "zero nuclear power", thus aligning with the program of the Green movements. At that point, the Energiewende had become a complex, multi-objectives program for change, not a simple Transition as described at the onset of the paper. The rest of the world turned to Globish and spoke of the Energy Transition (EnT). Each country added a layer of complexity to its own version of the EnT and told a series of narratives, quite different from each other. This is analyzed in the present article on the basis of the documents prepared by the "energy-community", which assembles hard scientists and economists, a group that the soft scientists of SSH call STEM. EnT, in its most recent and mature version, hardly speaks of energy any more but of GHG emissions. Therefore, EnT drifted towards the expression Ecological Transition (EcT). Both expressions are almost synonymous today. From then on, myriads similar expressions sprang up: Environmental Transition, Demographic, Epidemiological and Environmental Risk Transition, Societal Transitions, Global Transitions, Economic Transition, Sustainability Transition, Socio-Ecological Transitions, Technology Transitions, Nutrition Transition, Agro-Ecological Transition, Digital Transition, Sanitary Transition as well as various practices like Energy Democracy or Theory of Transition. Focusing only on EnT and EcT, a first step consists in comparing energy technologies from the standpoint of their impact on public health: thus, coal is 2 or 3 orders of magnitude worse than renewable energy, not to speak of nuclear. A second step looks at the materials requirement of Renewables, what has been called the materials paradox. They are more materials-intensive and also call on much larger TMRs (Total Materials Requirement). On the other hand, the matter of critical materials has been blown out of proportion and is probably less out of control than initially depicted. A third step is accomplished by Historians, who show that History is full of energy transitions, which did not always go in one direction and did not always match the storytelling of progress that the present EnT is heavily relying on. Moreover, they flatly reject the long-term storytelling of History depicted as a continuous string of energy transitions, from biomass, to coal, oil, gas, nuclear and nowadays renewables. Just as interesting is the opinion of the Energy-SSH community. They complain that the organizations that control research funds and decision makers listen mainly to the STEM-energy community rather than to them. And they go on to explain, sometimes demonstrate, that this restricts the perspective, over-focuses on certain technologies and confines SSH to an ancillary role in support of projects, the strategy of which is decided without their input: the keyword is asymmetry of information, which therefore leads to distortion of decision-making. They also stress the need for a plurality of views and interpretations, a possible solution to the societal deadlocks often encountered in Europe. As important and strategic as energy issues are in our present world, the hubris of both STEM and SSH communities may be excessive. Some level of success in making them work together may be a way to resolve this situation!
\end{abstract}

Keywords: sustainable development / energy transition / ecological transition / theory of transitions / STEMenergy community / SSH-energy community

\footnotetext{
* e-mail: jean-pierre.birat@ifsteelman.eu
} 
Résumé. Changement et transitions dans les systèmes énergétique, écologique et sociétal : story telling. Après avoir abusé de l'expression développement durable, il était nécessaire de définir un plan d'action pour passer du changement rhétorique au changement transformatif. Une solution a consisté à proposer le mot de transition comme feuille de route vers le niveau de changement nécessaire. Une transition est un passage d'un régime stable à un autre par une étape qui ne soit ni brutale ni dangereuse comme le serait une révolution, mais qui se produit suffisamment vite, néanmoins. La première de ces transitions a été la transition énergétique, au cours des années 2010, c'est-à-dire le passage vers moins d'énergies fossiles et plus de renouvelables. Elle a démarré partout à peu près à la même époque, mais l'Allemagne et son Energiewende a fait la course en tête. L'idée générale était autant de réduire les émissions anthropiques de gaz à effet de serre que de relancer une période de croissance économique basée sur des technologies vertes. Le désastre de Fukushima convainquit rapidement Mme Merkel de changer de cap et de partir en direction du «zéro énergie nucléaire », s'alignant ainsi avec le programme des partis verts. L'Energiewende était alors devenu un programme de changement complexe et multi-objectif et non plus une simple transition telle que décrite au début de cet article. Le reste du monde adopta l'expression en Globish d'Energy Transition (EnT), mais chaque pays ajouta une couche de complexité à sa propre version de l'EnT et proposa une série de récits nettement différents les uns des autres. C'est ce qui est au cour de l'analyse conduite dans le présent article, sur la base des documents de la «communauté de l'énergie», où on trouve surtout des scientifiques et des ingénieurs des sciences dures et des économistes, un groupe que les scientifiques des sciences molles SHS appellent STIM. L'EnT, dans sa version la plus récente et la plus mûre ne parle plus strictement d'énergie mais essentiellement d'émissions de gaz à effet de serre. Par conséquent, l'EnT a glissé vers l'expression de transition écologique (EcT). Les deux expressions sont d'ailleurs devenues quasiment synonymes aujourd'hui. Par la suite, des myriades d'expressions voisines sont apparues. Transition environnementale, transition démographique, transition du risque épidémiologique et environnemental, transitions sociétales, transitions globales, transitions économiques, transition de durabilité, transitions socio-écologiques, transitions technologiques, transition nutritionnelle, transition agro-écologique, transition numérique, transition sanitaire, de même que des pratiques variées comme la démocratie énergétique ou la théorie des transitions. En se concentrant sur l'EnT et l'EcT, une première étape a consisté à comparer l'influence des technologies de production d'énergie sur la santé publique: le charbon est ainsi 2 à 3 fois plus nuisible que les énergies renouvelables, sans parler d'énergie nucléaire. Dans une deuxième étape, on a analysé l'intensité en matériaux des énergies renouvelables, ce qu'on appelle le paradoxe des matériaux: elles sont en effet à la fois plus intenses en matériaux, font appel à des TMR plus élevés et à des matériaux plus rares. Néanmoins, la question des Matériaux critiques a été exagérée et est probablement plus sous contrôle qu'annoncé en général. Dans une troisième étape, ce sont les historiens qui ont pris la parole en montrant que l'histoire raconte une longue suite de transitions énergétiques, qui n'ont pas toujours pointé dans la même direction et ne sont pas appuyées sur la mise en récit de la transition énergétique que nous vivons en ce moment. Surtout, ils rejettent le récit de long terme qui présente l'évolution historique comme la succession ordonnée de transitions allant de la biomasse au charbon, au pétrole, au nucléaire et aujourd'hui aux renouvelables. Le point de vue de la communauté énergie-SHS est lui aussi intéressant. Elle se plaint de ce que les décideurs en matière d'énergie écoutent plutôt la communauté énergie-STM. Et elle explique et démontre aussi parfois que cela restreint la perspective, donne trop d'importance à un ensemble limité de technologies et ne laisse à la SHS qu'un rôle de faire-valoir ancillaire. Les décideurs ont donc une asymétrie d'information qui déforme les processus de décision. En ouvrant les analyses à une pluralité de vues on pourrait briser certains blocages sur l'énergie rencontrés en Europe. L'importance stratégique des questions d'énergie dans notre monde moderne fait penser que l'hubris des deux communautés est excessive et que ce n'est qu'en les faisant travailler ensemble que l'on pourra collectivement avancer.

Mots-clés : développement durable / transition énergétique / transition écologique / théorie des transitions / communauté STIM de l'énergie / communauté SHS de l'énergie

\section{Introduction}

Sustainable Development (SD) has become a universal guiding light - for international organizations [1], governments [2], NGOs [3] and business [4]; only individuals do not feel the need to claim adherence to Sustainability (S), which is rather a collective commitment. As a narrative, SD has become a moral compass, while, at the same time, it has hollowed out, with some people even calling it an oxymoron [5].
An action plan was needed to reach beyond the rhetoric of promises of Sustainability and the new narrative that has been following up on its track is that of Transitions.

The present article aims at sorting out the process by which the new trend has been emerging, from the Energiewende of Germany, which launched the phenomenon in Europe, to the Energy Transition in global English, the Ecology Transition that followed up close behind and now the theme of Transition, or Transitions, with or without a qualifier. 
It is a personal analysis rather than a review of previous reviews, as I am not aware of any discipline that has yet caught up with the intricacy of what has happenedalthough there are probably many candidate attempts [610].

Although the comment is probably unnecessary, we will not discuss here the case of the Transition metals ${ }^{1}$, although the Journal is dedicated to materials and metals to a large extent, a topic that would resonate with readers. The Transition metals are an idiosyncrasy of quantum physics whereas we will be talking here about a social phenomenon, maybe a historical one. The word Transition is also used in physics, solid-state physics, metallurgy and cosmology in the expression Phase Transition, which designates a variety of different phenomena depending on the discipline that uses $i^{2}$. This is not the topic of this paper either, although there is definitely a connection!

\section{Transition and Transitions}

The word Transition has a long history.

Its etymology is the latin transitio (-nis) that derives from the past participle of the verb transire, which meant "go or cross over". The word transient, has the same latin root (from the present participle of transire).

Transition is a word that is used to describe the change from one situation to a different one, thus a simple attempt at describing a time-dependent phenomenon, where two steady-state, stable situations are separated by a more or less abrupt change-which can be seen as positive or negative.

Mathematics would be a perfect tool for describing Transitions, but with sophistications not necessarily needed here.

History, on the other hand, sees as its duty to describe change, at least when it focuses on a diachronic description of the past. The discipline has a range of words at its disposal to describe change: evolution, mutation, metamorphosis, Transition, revolution, changeover, crisis [11], shift, switch, conversion, transformation, but also development, growth, advancement, progress, progression, expansion and their antonyms, ungrowth, decline, regress, regression, contraction, collapse, etc.: anything from a Heaviside distribution to a smoother and less steep function, to revert back to mathematics. A key point is how long the transition takes, years or tens of years? Room for controversies, cf. Section 7.3.

\footnotetext{
1 A simple definition (IUPAC) is any element which has an incomplete $d$ electronic sub-shell ( $\mathrm{Sc}, \mathrm{Ti}, \mathrm{V}, \mathrm{Cr}, \mathrm{Mn}, \mathrm{Fe}, \mathrm{Co}, \mathrm{Ni}$, $\mathrm{Cu}, \mathrm{Zn}$ in Period 4 of the Mendeleev table and more in the further Periods). Other scientists also consider elements with an incomplete $f$ sub-shell as inner transition metals.

${ }^{2}$ Physics: solidification, boiling, melting, etc. Solid state physics: magnetic Transition, Bose Einstein condensation, superconducting Transition, etc. Metallurgy: phase change in a multiphase diagram, etc. Cosmology: phase changes associated with symmetry breaking, close to the Big Bang.
}

In other languages, Mutation is Mutazione in Italian [12], mutation in French, 突变 in Chinese, der Wandel or die Veränderung in German, mutación in Spanish, перегласовка in Russian, mutation or förändring in Swedish, 変化 in Japanese, etc.

Historians also use the concepts of diffusion vs. invasion, similar to that of diffusion vs. convection in fluid dynamics, which has fed discussions and controversies regarding, for example, the "arrival" of the Celts in Europe or that of the Indo-Europeans ${ }^{3}$.

The word Revolution became popular with the English Revolution of 1688, which they call the Glorious Revolution in British history books, the American revolution (1765-1783), the French revolution (1789) and many more afterwards. Note that the word Revolution was still used in Russia in 1917 and in China in 1911, while the creation of the Popular Republic of China is simply referred to, today, as the Chinese Civil War (国共内战).

The word Revolution is also used in connection with deep changes in the world of scientific knowledge (the Copernican Revolution or, more generally, the series of Scientific Revolutions that followed) and in that of technical or technological practice (Industrial Revolutions, numbered from $1^{4}$ to 4 or $5^{5}$, today).

Therefore, to describe change, historians have two words available, depending on how quickly change happens: Revolution and Transition, see Figure 1. Authors choose the one that fits best their storytelling purposes. The distinction between the two is mainly due to the duration of the change but also to the height of the step.

In Geography, the word Transition also comes up, like in the program of the first year of high school in France [13]. It is a rhetorical device to impress the students with the idea that they are living in a changing world (un monde en transition) and that they should be ready to accept it (resilience).

In Demography, the word Transition has been used for a long time to designate a long historical process, which started in the 18th century in Europe and will probably end in the 21st in the rest of the world, during which the world

3 There is a strong school of historians which does not recognize Indo-European as a people who invaded Europe, but as a simple linguistic diffusion phenomenon. Another school, often led by the same historians, explains that the Celts never moved into central Europe, but that their technological episteme did. A gross analogy is that Europe is full of McDonald's restaurants even though the American never invaded Europe!

4 The 1st Industrial Revolution is usually meant to designate the use of coal, steam and pig iron made from blast furnaces that took place in the 18th century. However, there is also a habit of designating the Neolithic Revolution (sedentarization, agriculture and animal husbandry, first villages/small cities) as the 1st one.

5 The 2nd Industrial Revolution took place at the Transition of the 19th and 20th centuries, in connection with oil, electricity and steel. The 3rd one was related to the use of communication and information technologies. The 4 th one is related to digitalization and is stressed by the German expression of Industrie 4.0. The 5th one has been put forward by Japan and is related to the use of sophisticated robots. 
Revolution

Transition
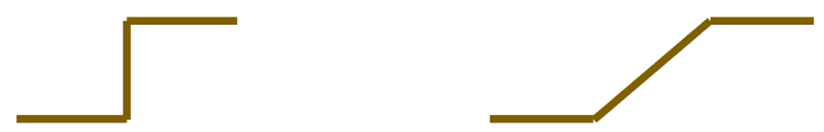

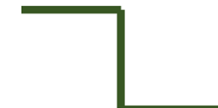

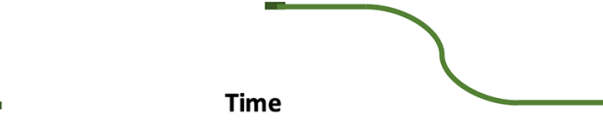

Heaviside function

Smooth function

Fig. 1. Revolution vs. Transition, from the standpoint of History (top) and Mathematics (bottom).

population transited from a period of high to low birth and death rates. The Demographic Transition is thus composed of two Transitions, the death rate Transition and the birth rate Transition. Both of them decrease with historical time, but are not in phase, time-wise: the death rate falls off first, because of progress in sanitation and medicine, while the birth rate falls off with a delay because it is related to cultural factors ${ }^{6}$. This causes the population to increase until both rates come close together again. This has resulted in a 10-fold increase in world population since the 19th century (cf. Fig. 2). While the Transition took about 100 years in Western Europe and in the United States, it dropped to 10 years in the case of Iran or China. This twoshot Transition is not unique and other examples will be analyzed in the course of the paper.

Note also that this dichotomic Transition is seen as good, positive where the fall in death rates is concerned and with mixed feelings regarding the exponential growth of world population.

Prior to a Change, either Transition or Revolution, there is usually a Crisis to which the Change brings closure.

Last comment in this introduction: the ancient Greek for the word Transition is $\varepsilon \nu \tau \rho o \pi \eta$ (entropy). We will see later, if we can extract some lessons from this seeming idiosyncrasy.

\section{The Energy Transition, German style (die Energiewende)}

The key policy document outlining the Energiewende ${ }^{7}$ was published by the German government in September 2010 $[15,16]$.

With hindsight, the inspiration of this policy was that an Energy Transition was in the making and that the

\footnotetext{
6 Particularly to the literacy and education of women.

7 Energiewende is usually translated by Energy Transition, but it means rather "Energy Turn", not simply a shift but a move in a chosen direction. The expression was first used by the Öko Institut, an Association, in a 1980 report.
}

government should take steps to give it direction and control it, by formulating a soft law .

The idea of the German Government was probably to ensure that two megatrends (the development of Renewable Energy ${ }^{9}$ in the sense that the price of the $\mathrm{kWh}$ was dropping on the one hand and the threat of Climate Change on the other, due to the combustion of fossil fuels) would have to be harnessed and directed towards economic growth (the so-called green growth) and the improvement of environmental conditions.

At the time, Nuclear Power was an important part of the German electricity grid (17 power plants in 2010) and it was seen as part of the solution or, at the very least, as a bridging technology ${ }^{10}$. More stock was put in renewable energy, mainly wind farms, especially off-shore ones and photovoltaics.

The expression of a flexible power plant fleet was used along with that of smart grid complete with provision for energy storage. Energy efficiency was also described as a central piece of the whole effort. Moreover, as coal was also part of the energy culture in Germany, it was mentioned in connection with Carbon Capture and Storage (CCS).

The legislative targets were greenhouse gas (GHG) reductions of $80-95 \%$ by 2050 (relative to 1990) and a renewable energy target of $60 \%$ by 2050 [16]. They were then described as "ambitious".

The Fukushima nuclear disaster took place on 6 June 2011. It created a shock worldwide and caused Germany to rewrite its energy targets, under the direct leadership of Chancellor Merkel: it was indeed decided to shut down all nuclear power plants by 2022. Needless to say, the Green political parties and NGOs applauded. The German vision of its energy system in 2012 is shown in Figure 3: all NP are gone by 2025 , the long-term trend is on slightly less energy consumption by 2050 compared to 2005 , with a mix composed of a majority of renewables complemented by a small fraction of natural gas and cogeneration with gas and coal.

The consequences of these strong policy decisions can now be analyzed in $2020[18-20]^{11}$.

Germany plans to shut down all its coal-fired power plants by 2038, by which time it would be relying mostly on renewables. The increase in renewables has outpaced the initial targets, as shown in Figure 4. Due to a long series of

\footnotetext{
8 As opposed to a hard law, which specifies what should be done or not done subject to a penalty, a soft law gives guidelines as to where a specific trend should be heading.

9 The contrary of Renewable is Depletable although it is often opposed to fossil fuels. There is indeed a confusion between the fact of being carbon-free and renewable, as, in practice, they designate the same kinds of energy.

10 The idea, then, was to increase the life of the NPP by 12 years.

11 The IER is a private, conservative US think tank, based in Washington DC and originating from the Institute for Humane Studies of Texas, founded by billionaire Charles Koch. The conservative and even denier's bias of Koch's organizations is well known. Therefore, we used the article with the utmost care.
} 


\section{The demographic transition in 5 stages}

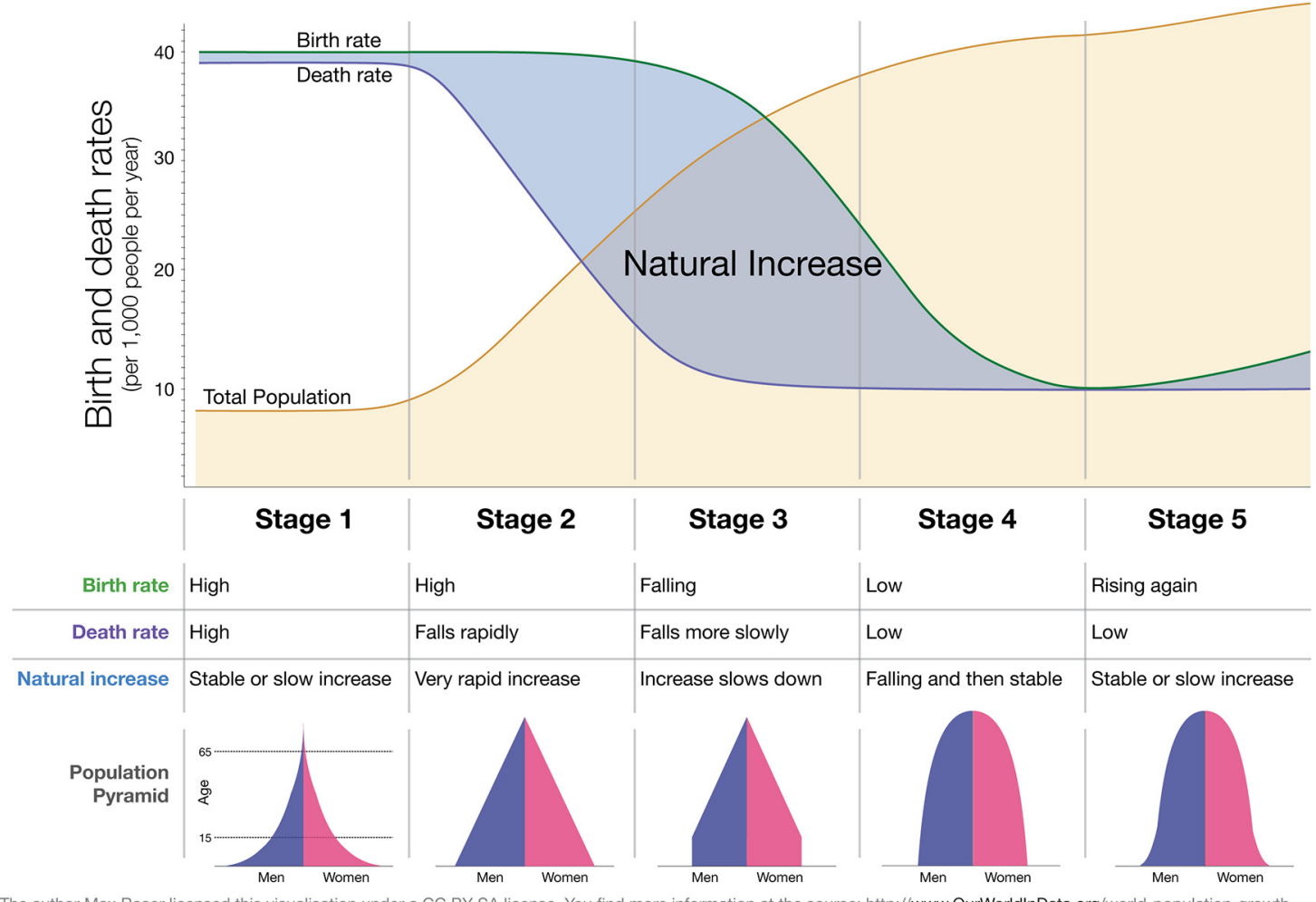

The author Max Roser licensed this visualisation under a CC BY-SA license. You find more information at the source: http://www.OurWorldlnData.org/world-population-growth

Fig. 2. The concept of the Demographic Transition (Source: Wikipedia [14]).

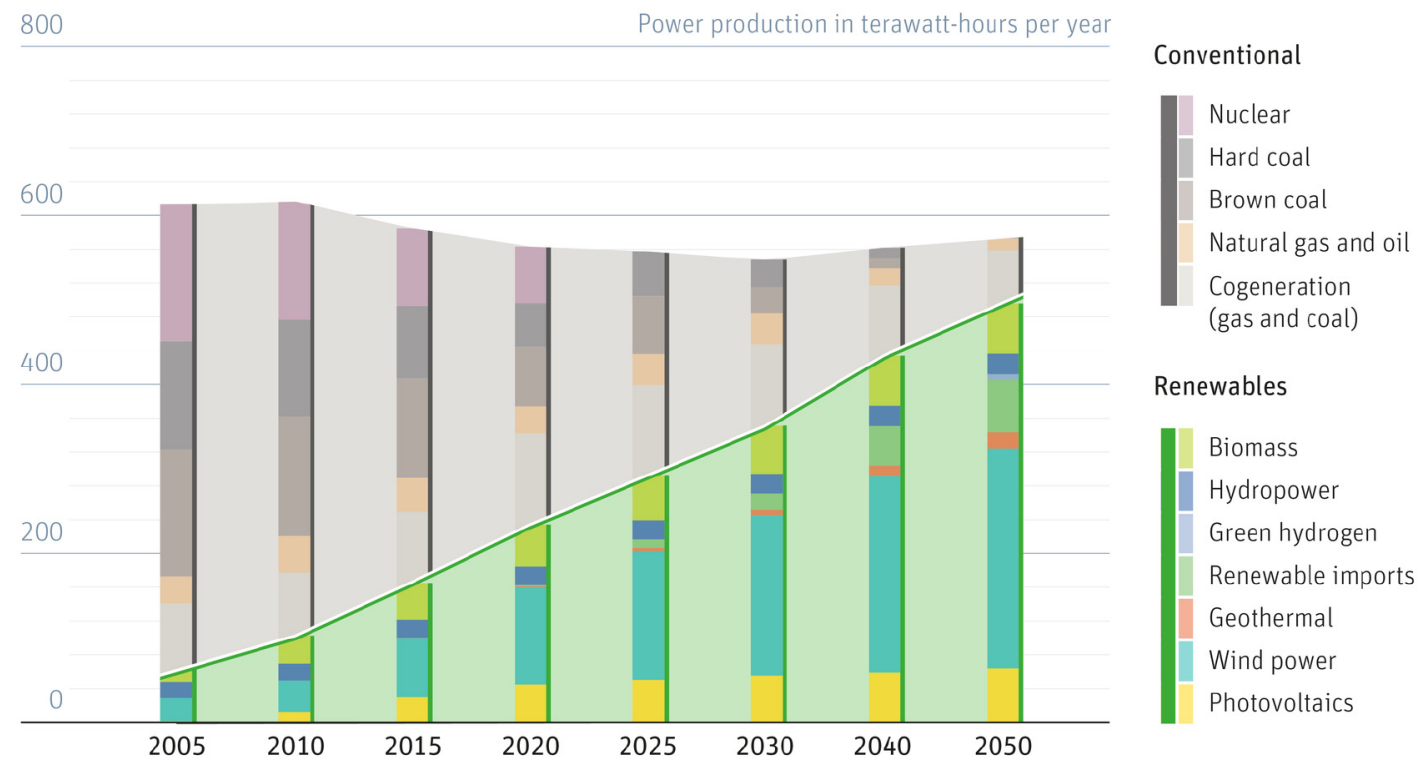

Fig. 3. Energy Transition plan in Germany in 2012 (https://creativecommons.org/licenses/by-sa/2.0/). 2005-2050 scenario. Source DLR and Fraunhofer [17]. 


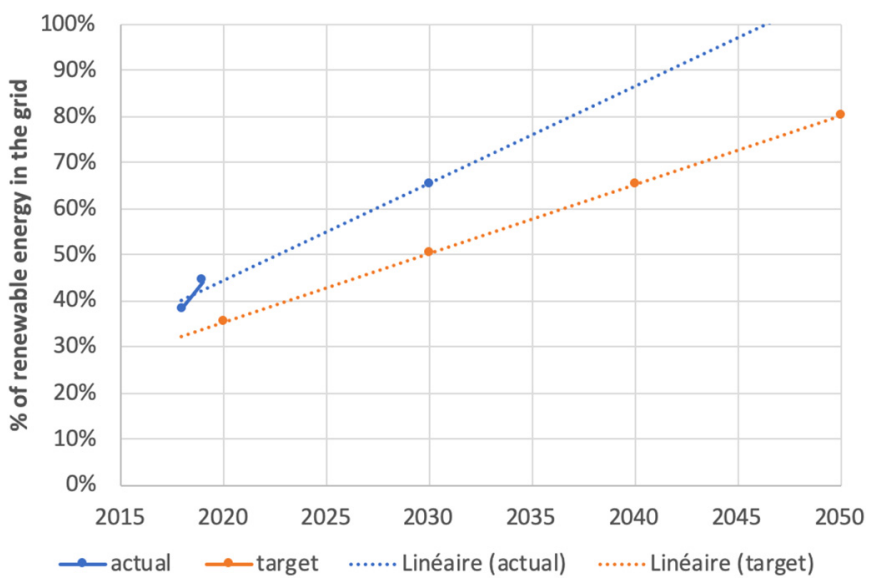

Fig. 4. Share of renewable energy in the electrical grid (Germany).

policy reformulations $[18]^{12}$, the target for 2030 would increase from 50 to $65 \%$, so that the final ambition should be reached by 2050 , setting the country on track to become carbon-neutral. Today, while coal remains the first energy resource, wind has stepped up to rank number 2 .

The downside of the policy, today, is that the country is behind its targets in GHG emissions. With a target of reduction of $40 \%$ vs the 1990 emissions, it only achieved $31 \%$ reduction in 2018 . The phased-out nuclear power has been mostly replaced by renewables as far as electricity is concerned, but this was not enough to reach GHG emission targets as in the rest of the energy system, namely road system and residential sectors, has been slower at adapting than planned.

There are other hurdles, like the fact that renewables are mostly located in the North of the country, while consumption lies in the South. The existing power lines are not strong enough to carry the power and public opinion is balking at building new infrastructures.

Last but not least, Germany will rely on electricity imports as soon as 2023 to balance its grid. Furthermore, the price of electricity in the country is significantly higher (50\%) than in France for example.

This is interpreted by references $[19,20]$ as a policy heading into a wall, mainly because of the size of government intervention which the IER objects to. This however, is only one biased scenario. Germany has been taking steps to be on target by 2050 and probably before.

If we analyze the Energiewende in terms of transitions, we see three transitions playing along: a nuclear power transition, a renewable energy transition and a low-carbon energy transition. The transitions are based on independent rationales. The first Transition came last. It modified the initial plan by making it more difficult to balance the grid without the baseline nuclear power and with such a high level of intermittent renewables.

As noticed in the case of the Demographic Transition, such a composite Transition offers opportunities for

\footnotetext{
12 Renewable Energy Sources Act in 2014 and 2017, Act on the Further Development of the Electricity Market in 2016, Commission on Growth, Structural Change and Employment in June 2018, Climate Action Programme 2030.
}

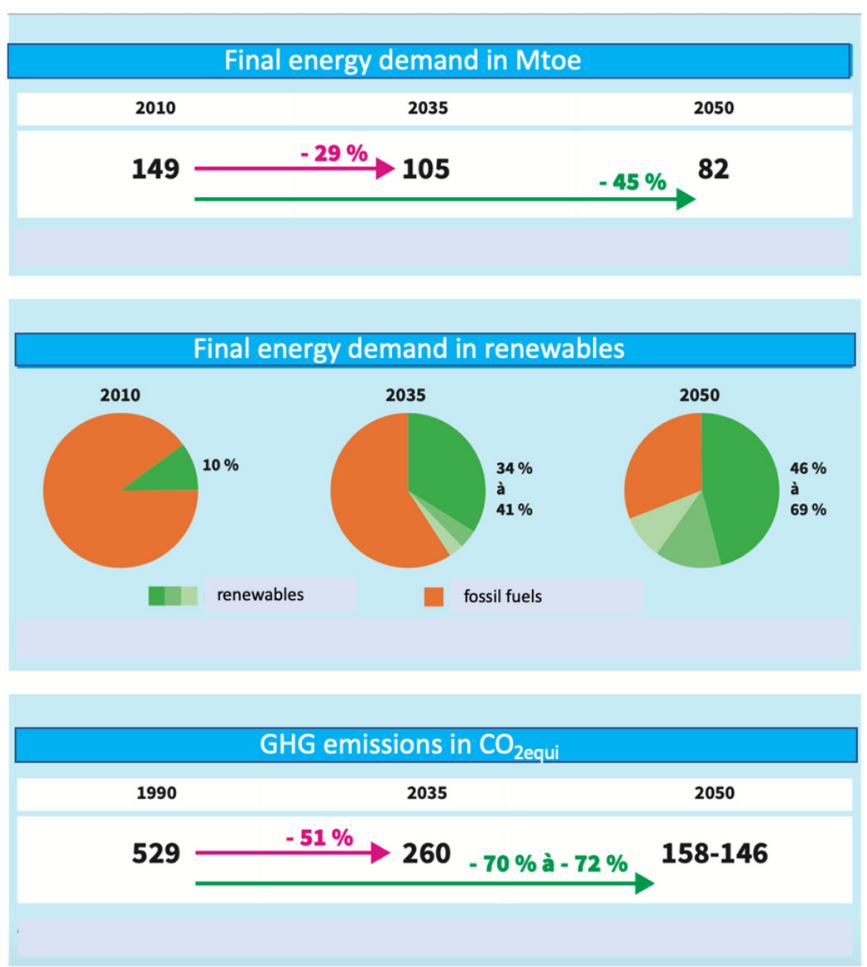

Fig. 5. ADEME's projections for the French energy system, until 2050 [23].

many outcomes, including some that are not necessarily compatible with the other transitions.

Was there an Energy Crisis in Germany, prior to the Energiewende? Not so very clearly: there was a lot of talk about peak oil but the deadline was pushed into an indefinite future, due to the exploitation of unconventional oil and gas. There was the matter of aging nuclear reactors, but the decision of extending their life was about to be made. What constituted a crisis was the Fukushima disaster, which occurred after the Energiewende had been launched: afterward, the transition was adapted to exclude NP and therefore the Transition became routed in solving a crisis, but not before.

Moreover, as mentioned in the introduction, the crisis may be seen as the dead end reached by the concept of sustainable development.

\section{The Energy Transition, elsewhere in the world}

The rest of the world, after Germany, adopted the concept of energy transition and acted on the need to promote it through soft laws.

\subsection{The case of France}

France adopted an energy transition law in the Summer of 2015 [21,22], which is the result of a long democratic process started in early 2012. Moreover, this is related to an older effort at introducing environmental targets in French Law, including energy efficiency but not yet the rhetoric of energy transition, called the "Grenelle de l'environnement" in September and December 2007. 


\section{Energy consumption by industrial branch plus the construction sector}

\begin{tabular}{|l|c|c|c|}
\hline Mtoe & $\mathbf{2 0 1 0}$ & $\mathbf{2 0 3 5}$ & $\mathbf{2 0 5 0}$ \\
\hline Primary metals & 6.2 & 6.8 & 5.6 \\
\hline Chemistry & 8.2 & 5.8 & 4.0 \\
\hline Non-metallic materials & 4.0 & 4.3 & 3.9 \\
\hline Agro-food industry & 4.7 & 2.5 & 1.8 \\
\hline Equipment & 3.7 & 2.5 & 1.1 \\
\hline Others & 4.6 & 3.9 & 3.3 \\
\hline Total (without construction) & $\mathbf{3 1 . 4}$ & $\mathbf{2 5 . 8}$ & $\mathbf{1 9 . 7}$ \\
\hline Construction sector & $\mathbf{2 . 4}$ & $\mathbf{3 . 2}$ & 3.2 \\
\hline Total (with construction) & $\mathbf{3 3 . 8}$ & $\mathbf{2 9 . 0}$ & $\mathbf{2 2 . 9}$ \\
\hline
\end{tabular}

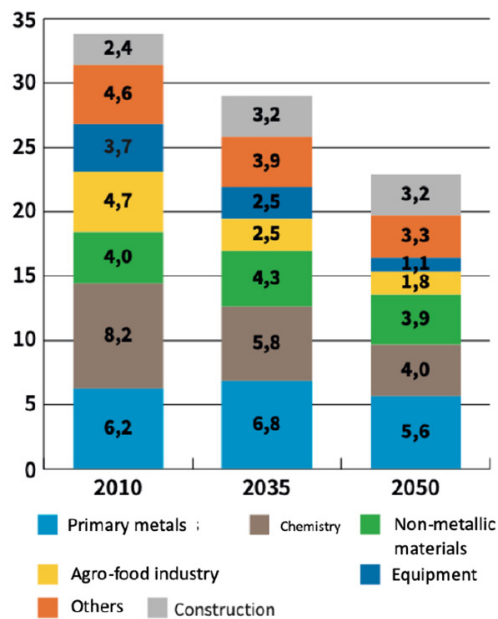

Fig. 6. ADEME's projections of energy consumption in the industrial and construction sectors (France) [23].
The law, called law of energy transition for green growth is meant to "promote an economic growth, model respectful of the environment, both lean and efficient in energy, in natural resource consumption and carbon use, which will be socially inclusive and foster a strong innovation potential, while making sure that business stays competitive". The law is supported by an action plan, which extends twice for 5 years in the future and is renewed every 5 years (PPE or Programmation pluriannuelle de l'énergie).

$\mathrm{ADEME}^{13}$, the French Energy Agency, in 2017 published projections up to 2050 to illustrate the longterm trend, cf. Figure 5 [23]. Note however, that while the German projections looked at the electricity system, the French ones focus on the Total Final Energy Consumption (TFEC), of which electricity is a part.

The target in energy intensity by 2050 is $45 \%$ below the level achieved in 2010, thus down to 82 MToe. This should decrease GHG emissions by $70 \%$ over the period. This is made possible by sharp increase a jump in renewable energy from $10 \%$ in 2010 up to 46 to $69 \%$ in 2050 , depending on the scenario chosen.

The story is significantly different from Germany's narrative, although the comparison is difficult as the perimeters are definitely not the same, a difference that is also part of the narrative.

Large GHG emissions cuts are on the agenda but not to the level of $100 \%$ in 2050 . The cut in overall energy consumption is larger over the period. The share of renewable energy in 2050 is less $(\leq 70 \%)$, mainly because a significant share of nuclear power is maintained, with variants (sharp reduction and business as usual). Note also a difference in the demographic projections, in the respective share of agriculture, industry and services, in the growth of PPS for mobility for example, etc.

An example of the evolution of energy consumption in the industrial and construction sectors is given in Figure 6.

\footnotetext{
13 The new name of ADEME, which used to be an acronym, is "Agence de la Transition Ecologique".
}

The overall final energy consumption in the French economy is shown in Figure 7: see the increase in electricity share from 22 to $39 \%$ over the period, the decrease in oil share and the growing importance of heat networks; renewables jump from 8 to $20 \%$ (outside of electricity, gas generation and heat network).

Since the study was published, a carbon-neutrality target for 2050 was enshrined in a new law passed in June 2019.

It would be possible to compare the German and the French longer-term projections, but this is not the point of the present article, where the focus is on Transitions, not on the technical content of these transitions.

Under the Energy Transition banner, the two countries on each bank of the Rhine told significantly different narratives. Germany communicated on the electricity grid, which is the easiest topic on which to insist if the message is about shutting down nuclear power plants and installing more and more renewables. France communicated on the overall energy system, which is a more general approach that gives the possibility to hide the status and the future of nuclear power, which is not yet decided in the country. Both energy transition concepts are complicated and quite far from that of a simple transition and even of a dichotomic one!

The word Transition therefore is used in these cases outside of its basic, simple lexical field: it is a kind of synecdoche or of metonymy. It designates than a simple transition in that case much more.

Last and not least, the narrative of the major countries has been changing with time, although staying under the same banner: Germany insists now on cutting nuclear power to zero on its own national territory, which was not the case when the Energiewende was first invented. Moreover, the country will import power from neighbors, much of which will be nuclear-based, as if this feature was erased as soon as the power lines crossed national borders! Similarly, but differently, France has also been reformulating its own version of the Energy Transition. 

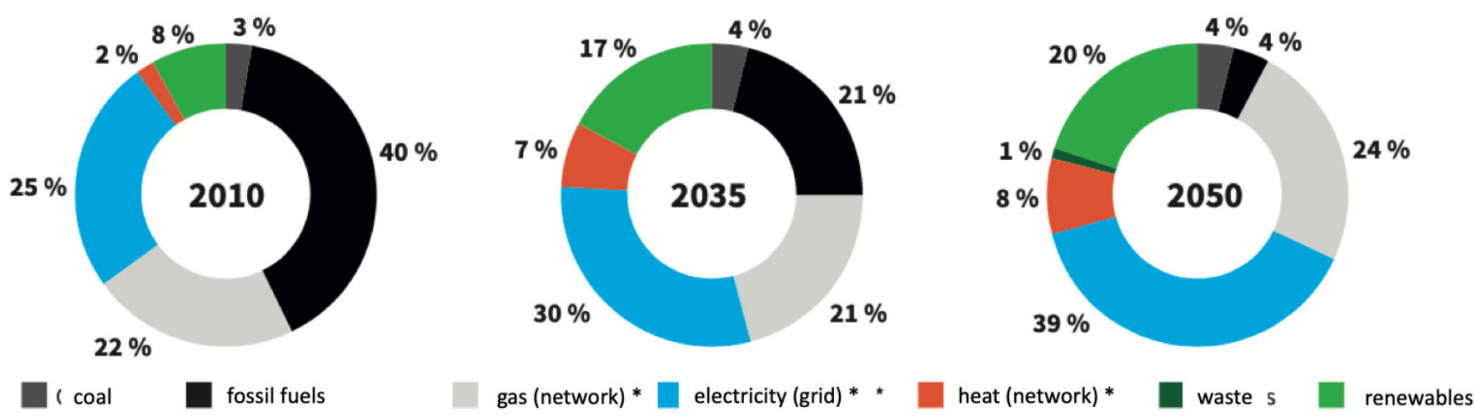

\begin{tabular}{|l|c|c|c|c|c|c|}
\hline Units: Mtoe/\% & \multicolumn{2}{|c|}{$\mathbf{2 0 1 0}$} & \multicolumn{2}{c|}{$\mathbf{2 0 3 5}$} & \multicolumn{2}{c|}{$\mathbf{2 0 5 0}$} \\
\hline Coal & 5.1 & $3 \%$ & 4.6 & $4 \%$ & 3.5 & $4 \%$ \\
\hline Fossil fuels & 59.3 & $40 \%$ & 21.6 & $21 \%$ & 3.6 & $4 \%$ \\
\hline Gas (network) & 31.5 & $22 \%$ & 21.5 & $21 \%$ & 20.0 & $24 \%$ \\
\hline Elecrcity (grid) & 37.3 & $25 \% \%$ & 31.9 & $30 \% \%$ & 31.8 & $39 \%$ \\
\hline Dsitrict heat (network) & 3.0 & $2 \%$ & 7.0 & $7 \%$ & 6.2 & $8 \%$ \\
\hline Waste & 0.2 & $0 \%$ & 0.5 & $0 \%$ & 0.6 & $1 \%$ \\
\hline Renewables & 12.3 & $8 \%$ & 18.2 & $17 \%$ & 16.0 & $20 \%$ \\
\hline Total (with construction) & 148.7 & & 105.1 & & 81.8 & \\
\hline $\begin{array}{l}\text { * part of the energy delivered by the networks and the grid are renewables } \\
\text { ** biogas, wood-energy, thermal solar, heat pumps FC and TWH, liquid biofuels }\end{array}$ & & &
\end{tabular}

Fig. 7. Final energy consumption in 2010, 2035 and 2050 by type of energy (France) [23].

Note that prior to governments and international institutions taking control of energy transition studies, very many NGOs devoted much time and effort in future studies designing leaner pathways to the future: the NEGAWATT is one such example among many [24].

\subsection{The rest of the world}

The theme of Energy Transition has been used all over the world as well as in international organizations.

The IEA speaks about global clean energy transition, thus focusing on GHG emissions and has developed a series of indicators (TCEP, Tracking Clean Energy Progress) that move up to intermediate indicators and finally arrive at a global one, the Energy $\mathrm{CO}_{2}$ Indicator, cf. Figure 8 [25]. They refer to a specific scenario, IEA's Sustainable Development Scenario (SDS), which exhibits composite goals: the Paris Agreement's well below $2{ }^{\circ} \mathrm{C}$ climate goal, universal energy access and substantially reduced air pollution. IEA's energy transition is also a composite concept.

The $O E C D$ being more involved with policy than the IEA, the Energy Transition is part of its working vocabulary: OECD has a GREEN Action Task Force, the mission of which is to "guide improvement of environmental policies in transition economies of Eastern Europe, Caucasus, and Central Asia (EECCA) by promoting the integration of environmental considerations into the processes of economic, social and political reform" [26].

The United Nations have a special program devoted to energy, $U N E P^{14}[27]$, where the expression energy transition is not stressed. The Sustainable Development Goals

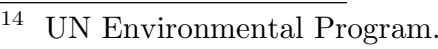

$(S D G)$ have goal 7 which calls for Affordable and Clean Energy. In both cases, the focus is on the goal, not so much on the path to reach it: the United Nations set the targets and member states define the path to follow in order to reach them.

The European Union is probably the International/ Regional Organization, which has gone the farthest in the nuts and bolts of the Energy Transition, setting targets early and revising them upwards regularly [28-31]. At the time of writing, the region is committed to $40 \%$ cuts in GHG emissions (from 1990 levels), $32 \%$ share for renewable energy, $32.5 \%$ improvement in energy efficiency by 2030 and to carbon neutrality in 2050 (the so-called Green Deal of the 2019 von der Leyen EU Commission).

Last but most emblematic is the roadmap of IRENA [32], the main result of which is shown in Figure 9.

These projections were built from the amount of energy-related carbon emissions can still be used to stay below a temperature increase of $2^{\circ} \mathrm{C}^{15}$, cf. Figure 10 . This means $66 \%$ renewable energy by 2050 in the TPES, doubling the share of electrical power and an $85 \%$ renewable share in the grid.

In Japan, METI prepared the 2015 "Long-Term Energy Supply and Demand Outlook" to 2030 which was adopted in July 2015. It introduces safety among the key objectives of energy policy, alongside the three "Es" of Energy Security, Economic Efficiency and Environmental Protection. Figure 11 shows the present energy status in Japan with a retrospective of 30 years. The Energy Transition in Japan is based on a rebirth of nuclear power and on renewable energy, biased towards photovoltaics with relative few wind turbines. The Plan for Global Warming

\footnotetext{
15 Paris agreement's $1.5^{\circ} \mathrm{C}$ target is equivalent to carbon
} neutrality by 2060 . 

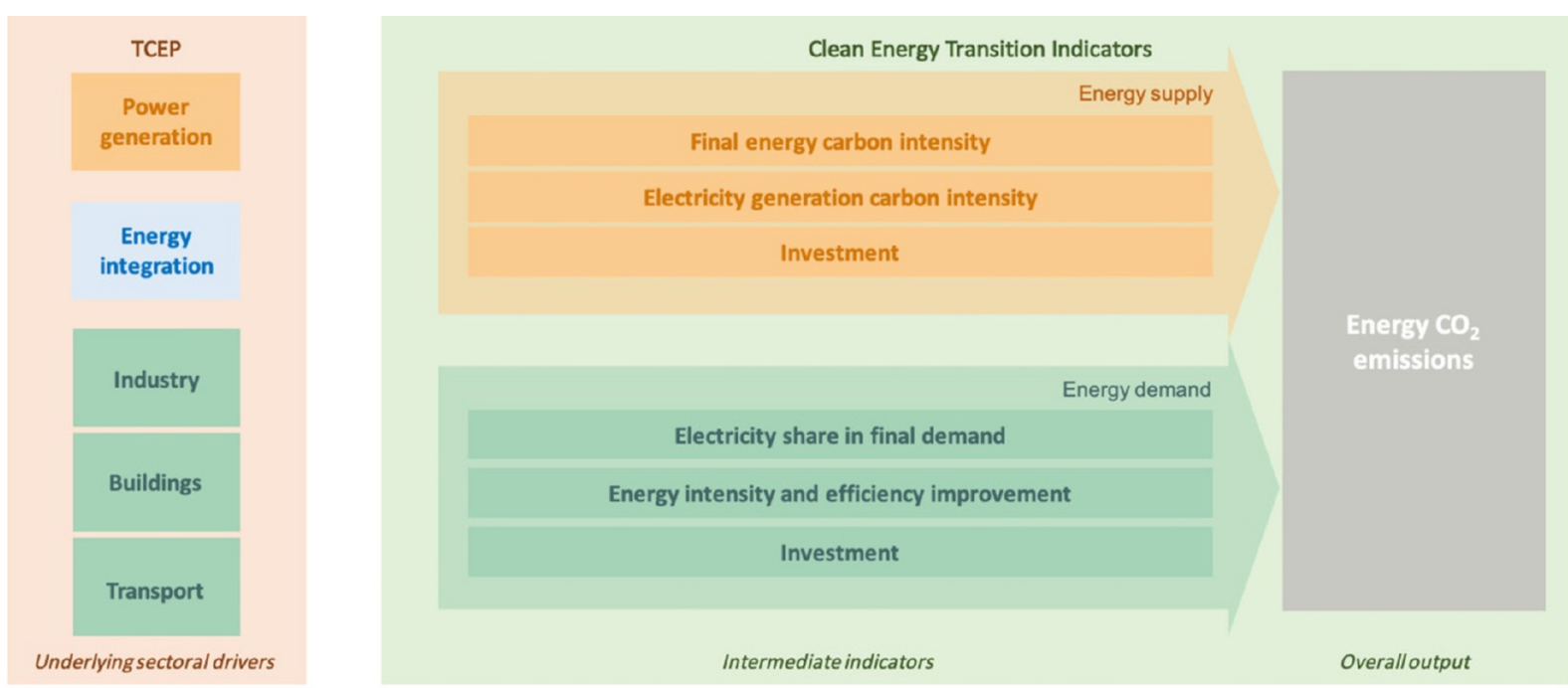

Fig. 8. TCEP, Transition indicators and Energy $\mathrm{CO}_{2}$ emissions: the IEA structure of energy transition indicators.

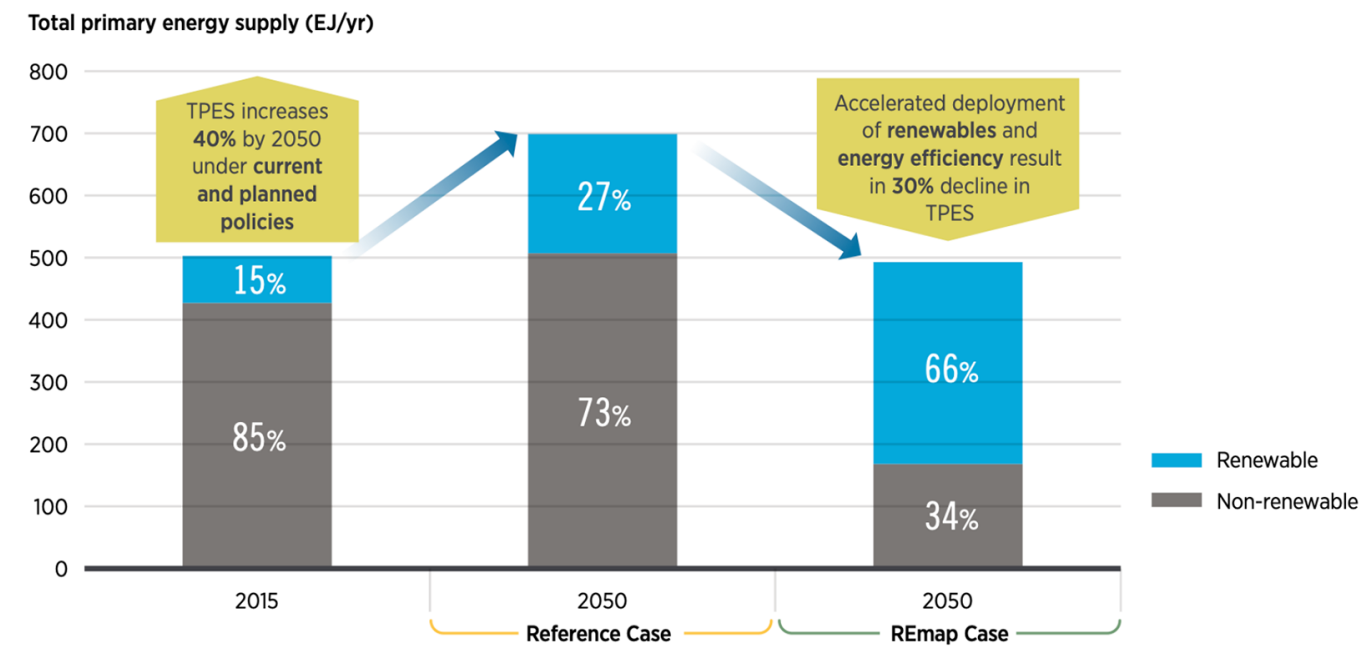

Fig. 9. Total Primary Energy Supply (TPES), world, according to the IRENA BAU and Remap scenarios.

Countermeasures is based on the Paris Agreement where Japan pledged to head towards cutting emissions by $80 \%$ by 2050 under the condition that this is compatible with economic growth. [34].

The case of China is important due to the size of the country and the change of tack in energy and climate policy demonstrated by its commitments in the Paris COP-21 meeting [35]. The National Strategy on Energy Production and Consumption Revolution (2016-2030) plans a peak of emissions in the middle of the 2020's [36], but some American experts believe that the peak has already been reached $^{16}$.

\footnotetext{
16 Moreover, the COVID-19 crisis is likely to accelerate the trend most certainly in 2020 but probably also in a more durable way, as major paradigm shift possibly.
}

Note that the word used in China in official documents is Revolution, not Transition in English and 革命 $^{17}$ in Chinese.

\subsection{Subcategories in the Energy Transition}

Table 1 shows the various meanings of the Energy Transition in the different countries and international organizations that were analyzed previously.

The common denominator is a zero-carbon world in 2050 or about, which is universally put forward. No country would advocate the energy transition for the sake of purely energy arguments, which is a transition of its own compared to the narratives of the time of the oil shocks

17 革命, gémìng, means revolution, although a major revolution would be 大革命, like the French Revolution is 法国大革命. A word by word translation of energy transition would be 能量过渡, néngliàng guòdù. 


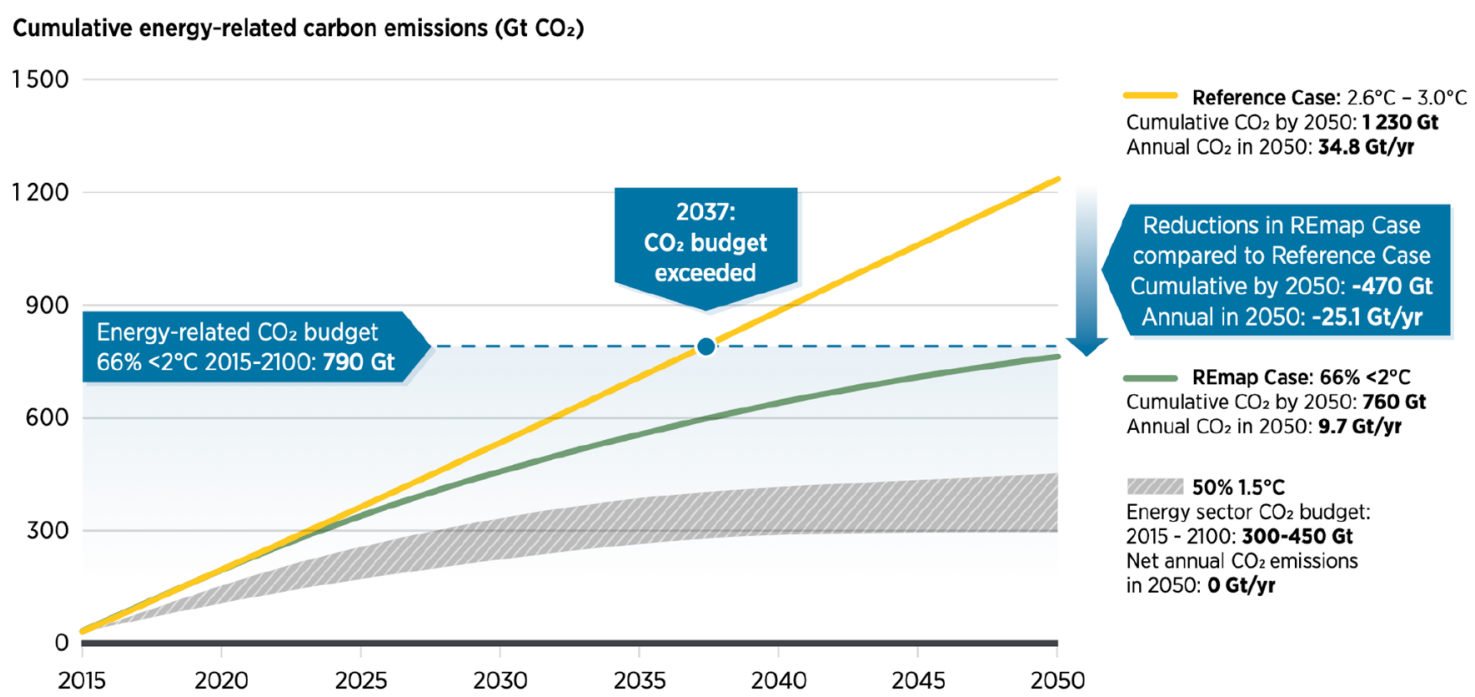

Fig. 10. Cumulative energy-related carbon emissions.

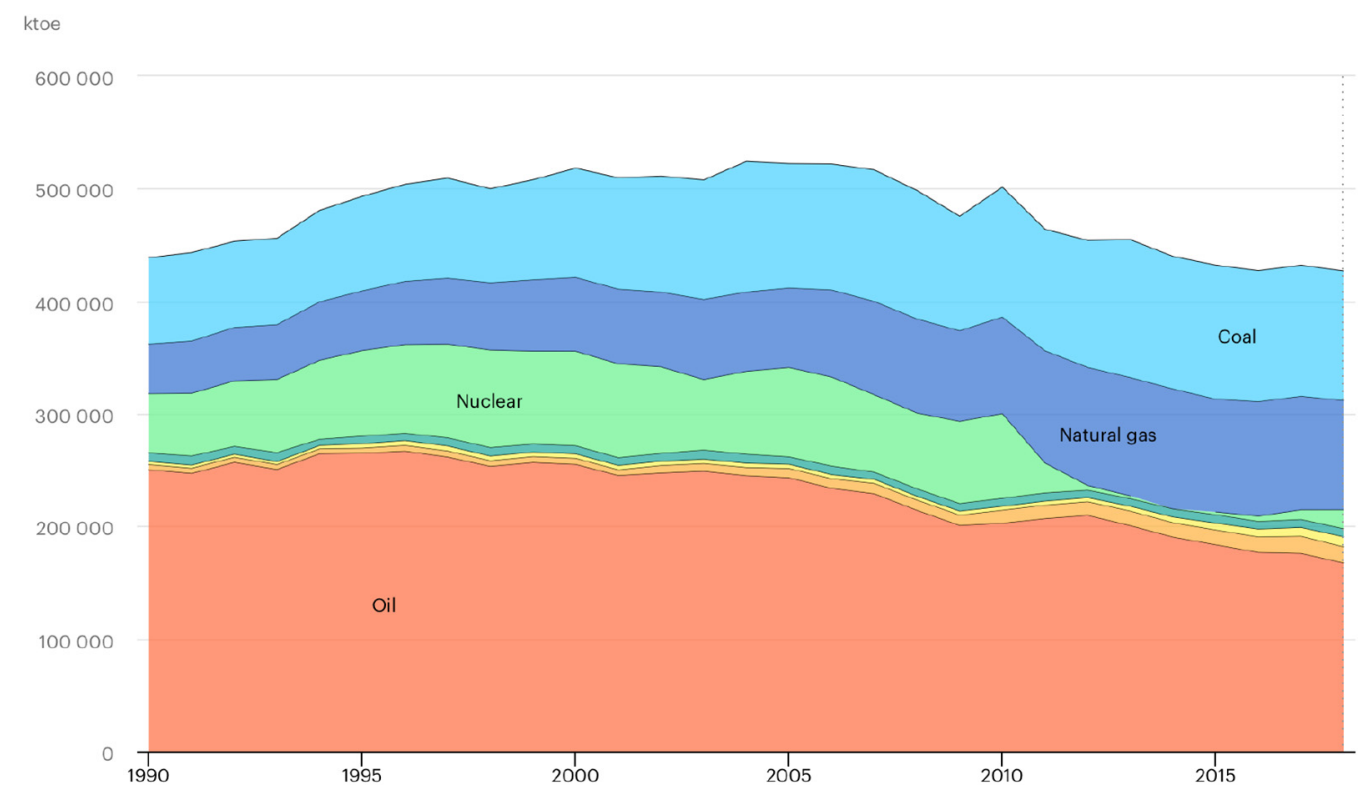

Fig. 11. Total Primary Energy Supply (TPES) by source Japan (1990-2018) [33].

of the 1970 s, or that of business in the face of the burden that energy price's weight on operating costs - for example in industry, or in the steel sector, where they account to $25 \%$ of OPEX.

Then countries add targets which have to do with industry competitiveness, with more general environmental objectives than simply Climate Change (air quality, biodiversity, etc.), with some social objectives (inclusiveness) and independence of supply. They insist on solutions, such as the increase in the share of renewable energy, or strong decisions regarding nuclear power (sharp shutdown, like in Germany, soft partial shutdown schedule like in France, focus on safety like in Japan, continuous erection of new NPP like in China), deadline for the shutdown of fossilfuel based power plants (except natural gas) and the expectation of Green Growth, as a new driver for continuing growth.
This is also a Transition in the narratives about energy, from independence of supply for countries ${ }^{18}$, lower energy price for business, a frantic search for energy efficiency for both - an argument rooted in the oil shocks of the late 20 th

18 We did not mention the US explicitly in the discussion, although the energy transition there was driven mainly by independence of supply, which was achieved by the exploitation of shale gas and shale oil. The country, which was a large importer, became independent of large oil producers and is now a net exporter. Note that this transition (another one!) was pulled by high oil prices and therefore that in such a case there is a contradiction between independence of supply and low energy prices. The low prices imposed by Russia and Saudi Arabia in March 2020 are threatening the profitability of producing shales in the US (equilibrium price for producing shale between 48$54 \mathrm{US} \$$ /barrel), but this is a fast-evolving chess game! 
Table 1. Taxonomy.

\begin{tabular}{ll}
\hline Subcategory-Taxonomy & $\begin{array}{l}\text { Country, } \\
\text { Organization }\end{array}$ \\
\hline
\end{tabular}

Climate change $\left(\mathrm{CO}_{2}\right.$ emissions target $)$

Safety in connection with nuclear power)

Energy security

Economic efficiency

Japan

Environmental protection

Climate change $\left(\mathrm{CO}_{2}\right.$ emissions target $)$

China

Climate change $\left(\mathrm{CO}_{2}\right.$ emissions target $)$

IRENA

Clean energy (SDG \#7)

Affordable energy (SDG \#7)

UN

Climate change $\left(\mathrm{CO}_{2}\right.$ emissions target $)$

Share of renewable energy

Energy efficiency

EC

Integration of environmental considerations into

OECD

the processes of economic, social and political reform

Sectoral target (industry, buildings, transport)

Define and follow indicators: final energy carbon intensity, electricity generation carbon intensity, electricity share in final demand, énergo $\mathrm{CO}_{2}$ emissions

Economic growth

Respectful of the environment

Lean and efficient energy

Lean and efficient carbon use

Socially inclusive

Independence of supply

France

Foster a strong innovation potential (Green Growth)

Business competiveness

Climate change $\left(\mathrm{CO}_{2}\right.$ emissions target $)$

Renewable energy and more (heat networks)

Nuclear power closure

Coal-fired power plants closure

Renewable energy

Low-carbon energy $=$ Climate change

Germany

$\left(\mathrm{CO}_{2}\right.$ emissions target)

Green Growth

century, towards a more holistic, sustainability-based rationale, which prepares for the next vocabulary shiftthe ecological transition.

The arguments, though, come from the community of energy experts, as they play a role in advising policy makers at political level. Therefore, from economists, energy economists, political scientists and energy engineers.
In conclusion, the concept of Energy Transition is hardly a simple transition but rather a composite one, charged with all the expectations and dreams of the stakeholders in the energy debates. No wonder that the concept is difficult to explain to a general public, since it means different things in different parts of the world.

Note the expression Clean Energy Transition, which takes on board energy and environmental aspects together.

Missing in the analysis so far is a Social Science and Humanity ( $\mathrm{SSH}$ ) dimension, an approach that will be picked up further in the paper (Sect. 7.4).

Figure 12 can serve as a summary of the energy transition section by illustrating the EU vision. All the rationales for the transition already discussed are there, plus another argument: "small is beautiful", the new energy system would integrate small systems - compared to the giant grid and giant utilities that run the show todaywhich would be driven by citizens, cities and energy cooperatives.

\section{The Ecological Transition}

The expression Ecological Transition was used in the 2010s, as soon as the proponents of the Energy Transition understood that they actually had in mind a more general Transition, which would be more clearly called Ecological Transition.

For example, in France, the environment minister, Ségolène Royale, published a roadmap for the Ecological Transition in 2015, as soon as the Energy Transition law was voted: she presented it as a rephrasing of the Sustainability law of 2010, the Ecological Transition towards sustainable development [37]. The general principles aimed at "fighting against climate change, reconquering biodiversity, achieving sobriety in the use of resources and reducing environmental health risks", "transforming the economic and social model for green growth", "creating ownership of the ecological transition" among the citizenry and liaising with parallel European and world efforts. It set 9 goals, which are detailed in Appendix A. Note that the present name of the Ministry of environment in France (2020), which changes with every new government, is Ministère de la transition écologique et solidaire, taking on board ecology and equity.

On the other hand, Ecological Transition was a household expression in the scientific ecological community at large, long before it was highjacked by the political community $^{19}$. Its meaning was more focused, imbedded as it was within the scientific field of ecology: both spatial issues, like the interface between ecosystems or biomes (ecological thresholds), and temporal issues, like the collapse of a population or that of a whole ecosystem (shifts, tipping points) [38,39]. A famous book from John Bennet, in 1976, an anthropologist, bears this exact name [40].

\footnotetext{
$\overline{19}$ S. Royale, a Socialist party member, belonged to a Socialist-led government which was associated with the Green Party. The political game at that time was for the generalist political parties to take ownership of ecological issues and thus to compete with the Greens on their own turf.
} 


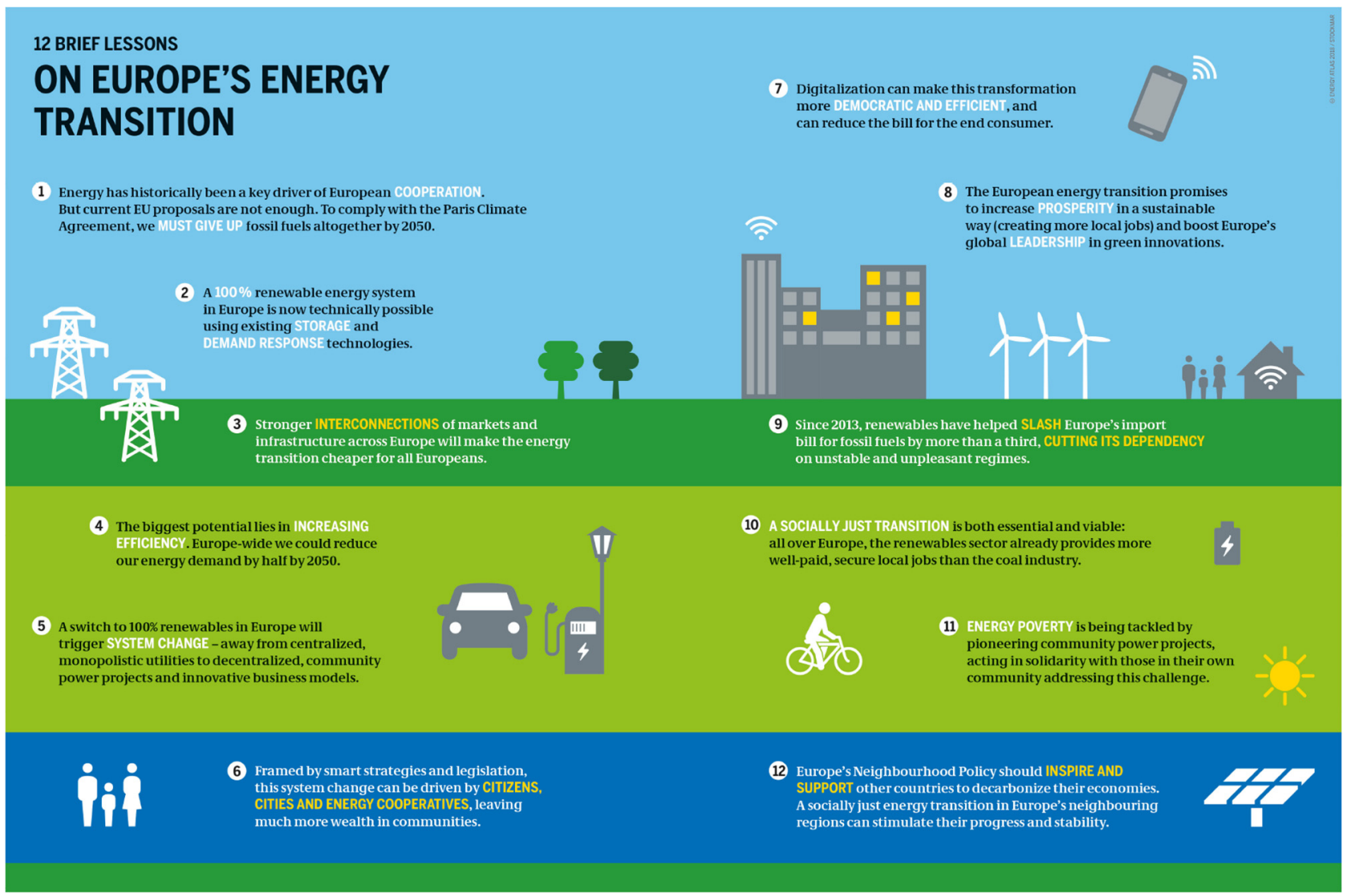

Fig. 12. Lessons from the energy transition in Europe. Source: European Commission.

As a matter of fact, there were similar uses of the expression Energy Transition, before the Energiewende surfaced in Germany [7].

In the EU, the Commission and the Parliament have agreed on a taxonomy to describe the field of intervention of the financial community, which would qualify as sustainable development or ecological transition: (1) mitigation and adaptation to climate change, (2) water and sea resources sustainable utilization, (3) transition towards a circular economy (4) avoidance of pollution, (5) conservation of biodiversity and ecosystems [41].

The UN, in the context of Europe and Central Asia, insists on the fact that beyond the use of buzz words ${ }^{20}$, what ought to be done is to move from a narrative about transition to an action plan stressing transformation [42]:

- "We know now that all the countries of the world need sustainable development - an awareness that has progressed faster than the real change towards this development path.

- Moving in such a direction is more than a green transition: it is a sustainable and inclusive transformation which demands a rethinking of economic, environmental and social policies and the way they relate to each other.../..."

\footnotetext{
20 In the city council elections in France of March 2020, many candidate lists had a green commitment, such as: "we will make sure that the city so-and-so will have accomplished its ecological transition to become carbon-neutral by $2030 "$ ".
}

- The report.../... argues that a new growth model is both necessary and possible - one which increases human development, advances equality and reduces the ecological footprint.

While the Energy Transition was definitely a composite transition, the Ecological Transition is even more so, as the UNECE example above demonstrates.

Actually, there are plenty of similar reports, which show a comparable degree of ambition [43,44]. They tackle the issue of proposing an action plan that would effectively deal with the ecological transition ${ }^{21}$, i.e. make it happen, and therefore lead to sustainable development in the strong sense of this term [45]. This is clearly different from and much more ambitious than a simple Energy Transition action plan, which has mainly a technical-economic objective. The social ambition is large, as a quote from [43] shows: "Equity is an integral dimension of sustainable development".

Transition, in the Ecological Transition case, can mean a Revolution! Note that Bruno Latour calls the transition the Ecological Mutation, an expression that may be even more radical than the word Revolution $[46,47]$.

There is a clear Ecological Crisis, to which the Ecological Transition aims to bring closure.

21 Or so they claim, with the hubris that is associated to the energy community! 


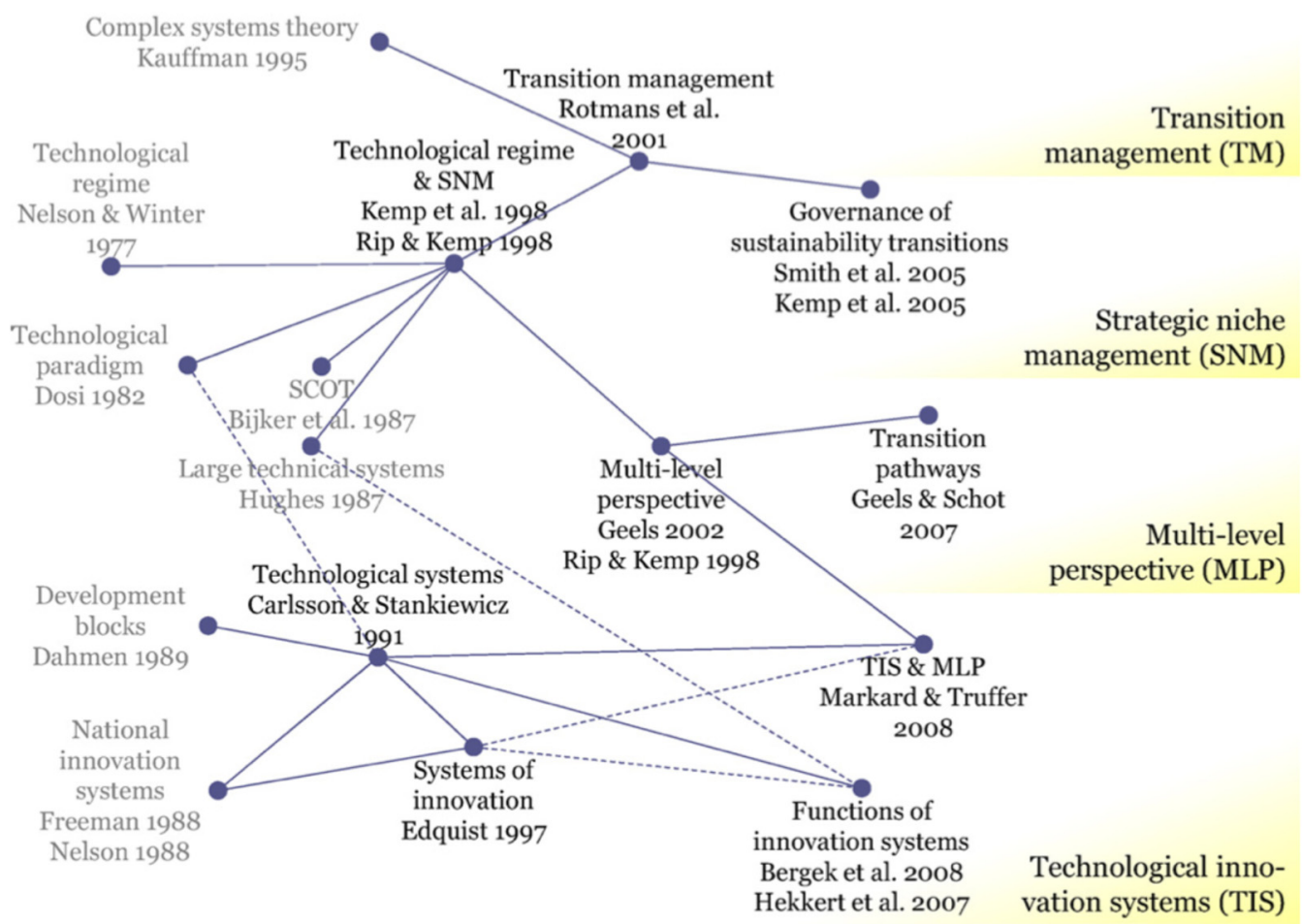

Fig. 13. Sustainability transitions [53].

\section{Other Transitions}

The word Transition has been associated with a wide range of other domains, explored by various communities:

- Environmental Transition, almost synonymous to Ecological Transition, but narrower [48].

- Demographic, Epidemiological and Environmental Risk Transition, a discipline that explores the reasons for the Demographic Transition: the on-going COVID-19 episode (at the time of writing) would qualify to fit in this category [49].

- Societal Transitions, more ambitious but also apt to mean very different things. The topic is related to Transition Management, a governance technique which tries to orient existing dynamics towards transition goals chosen by society $[50,48]$.

- Global Transitions in the broader fields of health, energy and technology [51].

- Economic Transition discusses the switch from a centrally-planned to a market-based economy [52].

- Sustainability Transition: Figure 13 from [53] proposes a classification of approaches in the field from a Business Administration standpoint. The International Journal of Transitions and Innovation Systems [54] as well as the Journal of Environmental Innovation and Societal Transitions [55] serve the same research community.

- Socio-Ecological Transitions is an expression used as a buzz word in [56].

- Technology Transitions is a concept used to identify technical solutions to the various transitions. It is often based on a techno-optimistic view of the world. Cf. the Office of Technology Transitions of the US DOE [57].
The Food or Nutrition Transition (transition alimentaire), the transition of the food value chain that would steer the sector towards sustainable development. Part of it may be the organic transition, what is called "bio" in Europe. The Food Transition has been taken up by the European Commission as part of its Green Deal policy, which is to serve as the guiding light of the von der Leyen Commission [58]: it is called the Farm to Fork policy (F2F) and it includes both the food and nutrition transition as well as a program for agriculture to preserve biodiversity [59].

- The Agro-Ecological Transition, a subset of the Food Transition, upstream of the food value chain.

- The Industrial Transition Plan, a present project of ADEME to build roadmaps for every economic sector (in France) to change and meet the targets of the Stratégie Nationale Bas Carbone (SNBC).

- The Digital Transition is a strong story told by the EC, independently of the other transitions mentioned before. It is claimed to be the basis for the 4th (or 3rd?) Industrial Revolution, that ought to overwhelm industry, services and administrations: it is a definitely technooptimist standpoint, using other magic words like Artificial Intelligence (AI), Internet of Things (IoT), $5 \mathrm{G}$ communication, etc.

- The Sanitary Transition, which is related to the Demographic Transition, deals with the present megatrend in terms of public health, i.e. on the one hand a promise of a future where the healthy life expectancy would increase significantly, and on the other hand a future plagued by new diseases, stemming from zoonoses or from old age (degenerative diseases). 
Some of these expressions are disciplinary terms, used outside of the Transition narrative analyzed in the present article, e.g. Economic Transition. Some are in continuity with our narrative, extending it further but based on the same method of analysis, e.g. the Nutrition Transition. Sometimes, the expression is a buzz word, riding on the popularity of the Transition storytelling, e.g. SocioEcological Transitions. In all cases, these are composite Transitions.

There is also a grassroots movement, sometimes called Energy Democracy [60], driven by associative or nonpartisan activists, which uses the word Transition alone, without any further qualifier, to get people, citizens, small cities, but also business, public structures, associations involved in a practical way in the concretization of that Transition, i.e. in the march towards Strong Sustainability.

Transition-org [61] is a typical organization in this community: it offers membership the service of a Think Tank open to its members and a University, with the objective of meeting the major challenges related to ecology, society and digitalization. Note that the word digitalization, one of the strong narratives of the European Commission, has now joined the Transition Narrative and is presented as part of a holistic view of Transitions.

Le "Collectif pour une transition citoyenne" (Collective for a citizen transition) federates various organizations (27) involved in the ecological, social and human transition and claiming independence, non-partisanship and non-sectarianism - a typical collection of words used by green and leftwing organizations. One of its two projects was to support groups engaged in the French municipal elections of March 2020 and hopefully get their agenda adopted by newly elected city councils [62].

Activists and transition research scientists involved in Transition Studies [63] get together in international organizations like the Sustainability Transitions Research Network [64] or the Transition Research Network [65].

Different disciplines speak about a Theory of Transition: - Psychology is interested in phenomena which accompany deep change in an individual's life. They are related to mourning and acculturation. The management of intercultural differences also shares some of the concepts and methods [66]. Schlossberg's Transition Theory is thus used for example in the field of education [67]. This is out of scope of the present review.

- Business administration, in as far as it is interested in innovation, has developed a theory of transition that they also call change management. It is related to innovation theory and future studies or prospective methodology and is based on the distinction between three scales of change, micro, which they call "niches", meso, which they call "socio-technical regime", and macro, which they call "socio-technical landscape", cf. Figure 14. This methodology could be used in connection with the present paper, although it is more oriented towards future studies than towards the analysis of on-going or past trends and it is a bit confusing.

Note that detailed solutions likely to deal squarely with the ecological crisis and thus to ensure a smooth Energy and Ecological Transition are rarely discussed in the kind of literature that was reviewed. In particular, the implementation of a carbon price, with the European ETS for big, energy-intensive industry ${ }^{22}$, a carbon tax for everyone $\mathrm{else}^{23}$ and a border tax to protect a carbon-virtuous region against less-virtuous trading partners is left out [69]. Of course, it is discussed elsewhere, see for example [70].

At this point, the concept of Transitions has become fairly universal and, in the process, has lost its sharp edge and become rather muddled. Maybe this is the point where one should remember that, in ancient Greek, Transitions were called entropy: the use of the word Transitions, in its broad variety, creates more confusion and intellectual chaos than clarity of concept - a definition of entropy! More often than not, the expression functions as a buzz word, a communication ploy, a simple tool for storytelling.

In the rest of the paper we will therefore revert back to the two expressions that we started with: Energy and Ecological Transitions. As a matter of fact, it was shown that they are actually one and the same thing.

\section{Other disciplinary prisms through which to explore Transitions}

What is left to do is to look for treatments of the concept of Energy and Ecological Transitions from a different disciplinary perspective than the mainstream energysustainability narrative.

Discussed will be the connection with health, occupational and public, with critical materials requirements, with the analysis of past Energy Transitions by historians and what lessons they learned for the on-going Transition, and with the approaches that Social Science has developed to deal with energy.

\subsection{Transitions and public health}

Let's start from a fairly quantitative perspective, i.e. introducing health issues into the analysis of energy technologies. Thus, asking if the Energy Transition, which has so many virtues in terms of environmental and economic benefits, matches them by being also virtuous in terms of occupational and public health. Please refer to Figure 15.

Renewable energy is clearly much safer than any of the more classical technologies. Fossil fuels-based power plants are the worst, by far. Nuclear power lies in between, because of the logarithmic horizontal scale: as the data shown in Appendix B demonstrate, however, it is actually in the same family as renewable energy, not fossil fuels $(0.074 \text { against } 62.32)^{24}$.

The high figures for fossil fuels are due to the estimates of premature deaths caused by air pollution, which have recently become widely available (4.8 million premature deaths per year, worldwide) [71].

\footnotetext{
22 About $16.61 € / \mathrm{t}_{\mathrm{CO} 2}$ on 23 March 2020, falling sharply. $2344.6 € / \mathrm{t}_{\mathrm{CO} 2}$ in France since November 2018 and $25 € / \mathrm{t}_{\mathrm{CO} 2}$ in Germany, effective in 2021.
} 


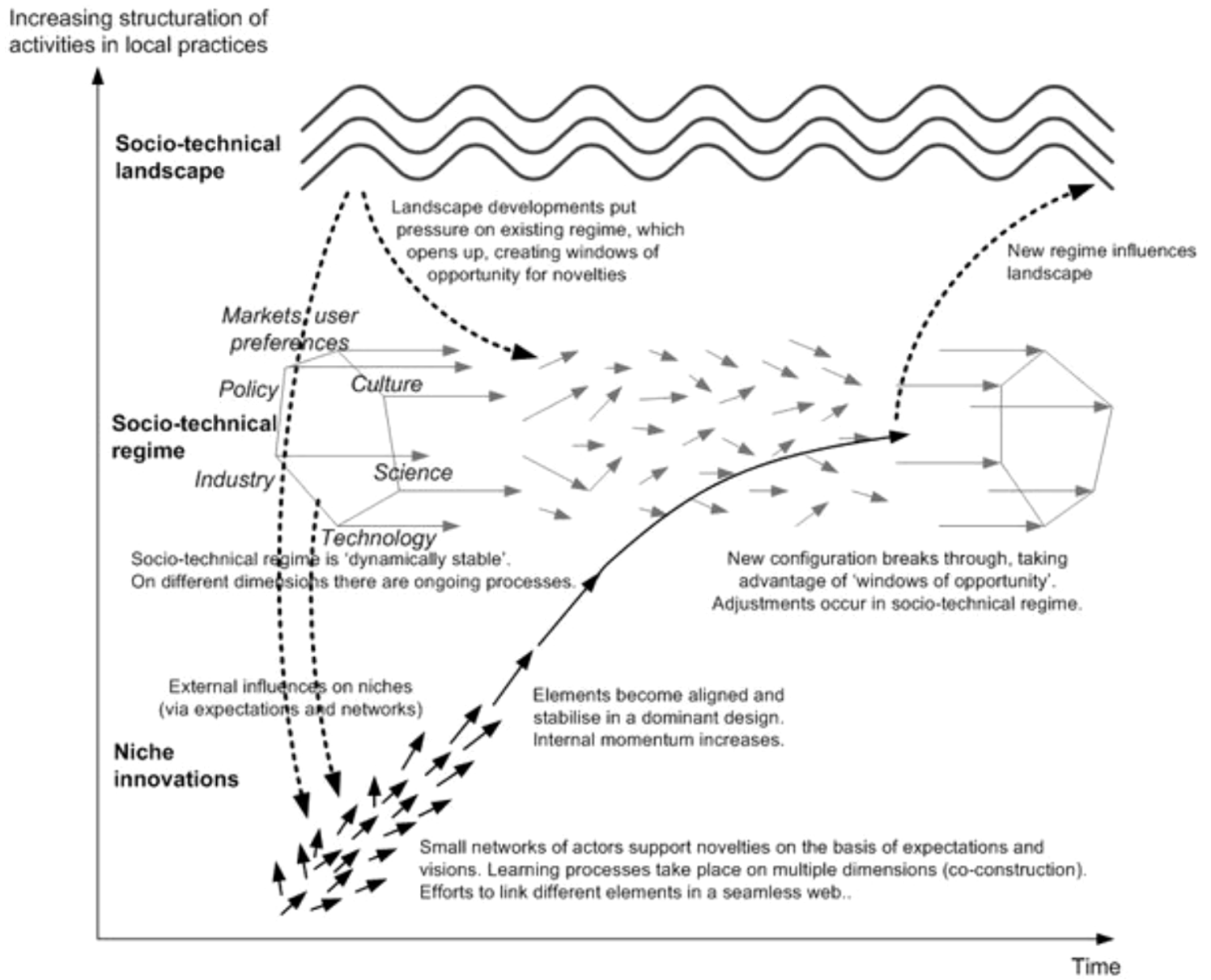

Fig. 14. Theory of transitions according to Geel [68].

From this analysis of health matters, the Energy Transition is therefore fully in line with its environmental objectives: renewables do bring benefits for both. It is a pity that this argument is not often made in favor of the ET.

Health has its own transition, the epidemiological transition, which marks the point in time when contagious diseases were considered under control, thanks to vaccines and drugs, and the focus of medical attention switched to chronic and degenerative diseases [72]. The present coronavirus pandemic questions the concept or, at least, shows it does not replace the old one: the transition, in this case, is actually a fork, with both a new paradigm and the old one continuing in parallel.

\subsection{Transitions and materials need}

Another issue is related to materials, from two different standpoints:

\footnotetext{
24 The point is not to make a controversial statement that would antagonize anti-nuclear activists. Their argument is based on different criteria related to a hypothetical nuclear accident that never quite happened but might.
}

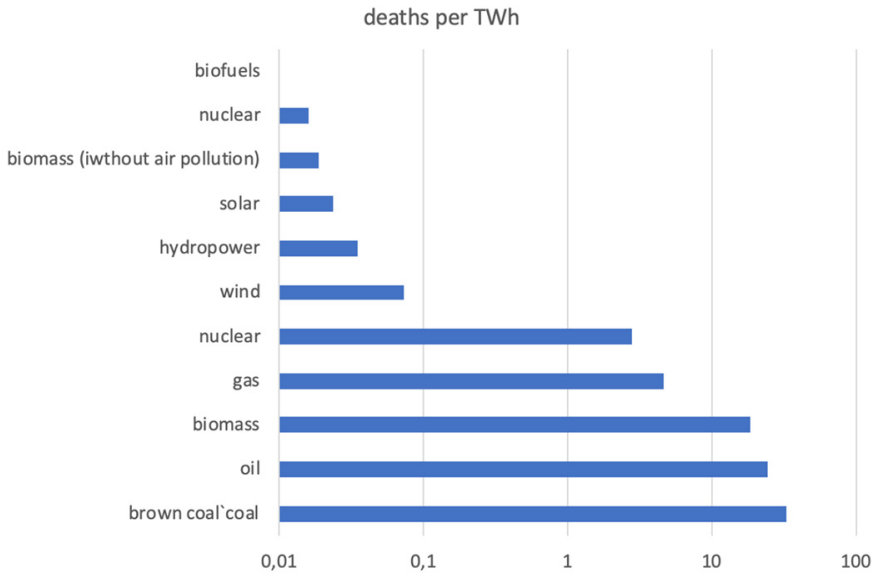

Fig. 15. Number of deaths (occupational and air pollution) due to the production of $1 \mathrm{TWh}$ relative to various electricity generation technologies.

- One is the material intensity of electricity generation as a function of power plant technology. Figure 16 shows the steel intensity of various types of power plants. The leanest power plant, from this point of view, is a nuclear 


\section{Fe (kg/GWhel)}

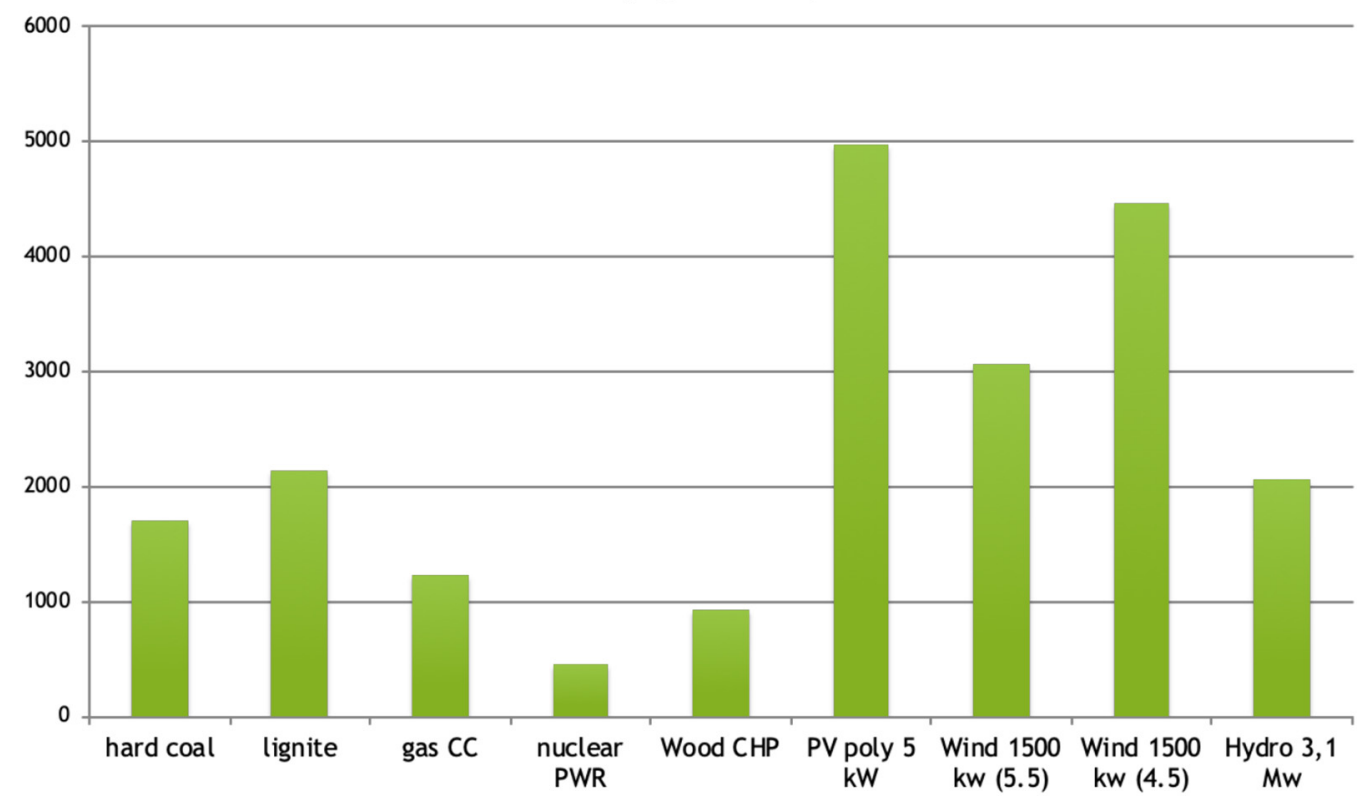

Fig. 16. Intensity of steel use in a power plant (authors' own diagram).

one. The most steel-intensive is a solar farm, followed closely by a wind farm - they require between 10 and 8 times more steel than an NPP. The rationale for this is that the energy density of the various technologies follows the same order of merit, because nuclear energy is far "denser" than gravity-there is thus a strong determinism imposed by physics! What is shown here for steel is also true for copper and concrete.

- The other one is related to the material paradox, i.e. the fact that renewable energy requires using rare and expensive materials and thus make it necessary to prioritize low-carbon emissions against the depletion of scarce raw material resources. The magnitude of the phenomenon, however, may have been overstated [73], since, first of all, rare earths are not rare from a resource point of view and because most on-shore wind farms do not use any! The payback time in terms of materials of such a wind farm is 12 months $(1 / 20$ th of the wind turbine life) and the $\mathrm{CO}_{2}$ intensity of electricity was $12,7 \mathrm{~g} \mathrm{CO}_{2} \mathrm{eq} / \mathrm{kWh}$ when the European grid was at $487 \mathrm{~g} /$ $\mathrm{kWh}$ [74].

However, the relevant critical elements are not simply rare earths, cf. Figure 17, but also Platinum Group elements, special elements for photovoltaics and a few more like lithium, cobalt, silver and rhenium.

The case is not so clear cut for solar power and even less so for energy storage.

Other authors analyze TMR, the Total Materials Requirement, which adds up all the material flows that have to be marshalled to produce a good, not simply the material amount imbedded in the good itself [75]: they point out the amount of materials that would need to be handled by the appropriate logistics in order to accomplish the Energy Transition by 2050 (Fig. 18).
These materials issues are part of the mainstream discussion about energy and ecological transition.

\subsection{Energy Transitions in History}

The long history and prehistory of man can be told in terms of energy, with many regime changes on the way that qualify as Energy Transitions.

The concept of energy is young: it developed into the modern notion of energy as used in Physics only in the late 19 th century, when thermodynamics was fully outlined [76]. In the Middle Ages and before, there were two independent concepts, heat (fire) and work that were connected in a coherent way only in the middle of the 19th century when the principle of equivalence was formulated, what is known today as the first law of thermodynamics (Nicolas Léonard Sadi Carnot and James Prescott Joule). For most of History, energy was work, mechanical work.

Various forms of energy were harnessed by mankind and their succession has been used to tell a long-time narrative of History, something similar to the use of materials to outline the passage of historical time ${ }^{25}$. " $\grave{A}$ l'âge de l'énergie organique rare aurait succédé l'âge du charbon, puis celui du pétrole et de l'atome, avant de laisser la place à l'âge des énergies renouvelables" [9].

What follows is a eurocentric narrative. In China, one would tell quite a different story!

In the Paleolithic, there was little need for energy as the groups of humans were hunter gatherers: they used heat, in the form of fire, to cook food and to prepare tools and weapons, and human strength (work) to carry their meager viaticum or throw spears. Human sedentarization in the

$\overline{25}$ The Ages of Stone, of Bronze, of Iron, of Silicon, etc. 


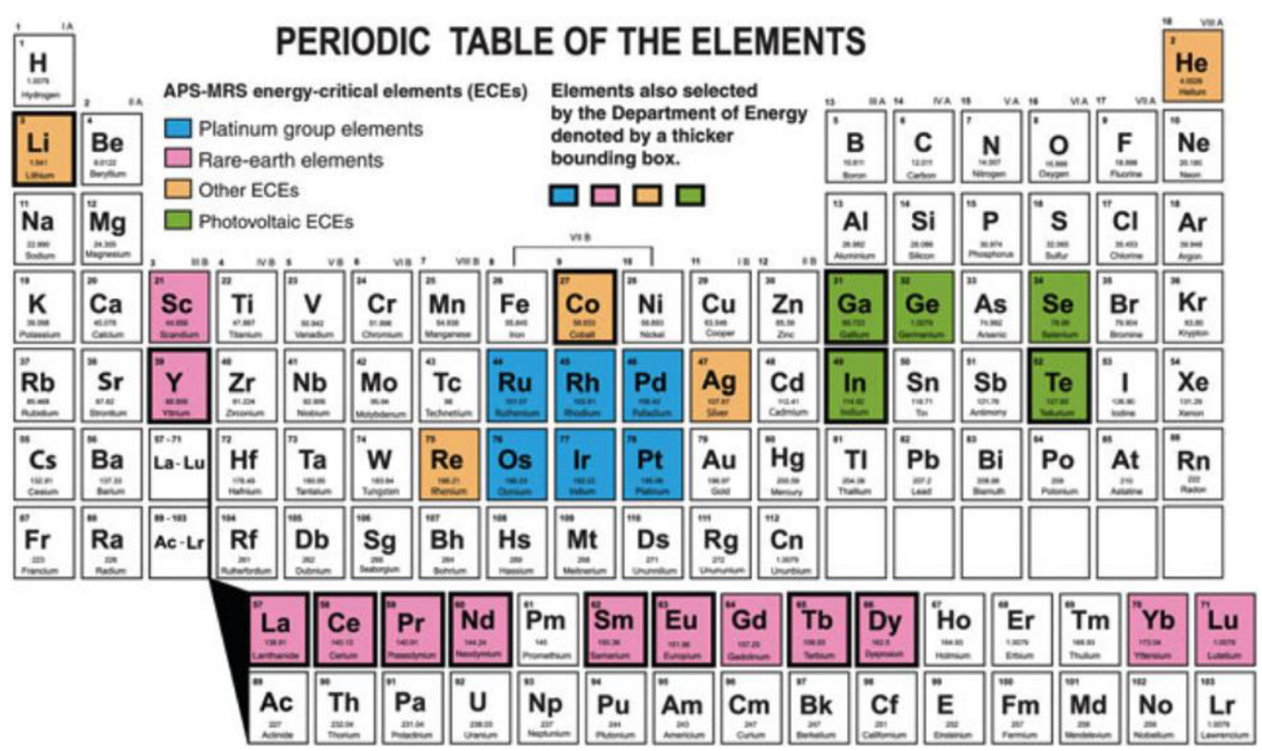

Fig. 17. ECE including Rare Earths, Platinum Group, photovoltaic elements and other elements (2010).

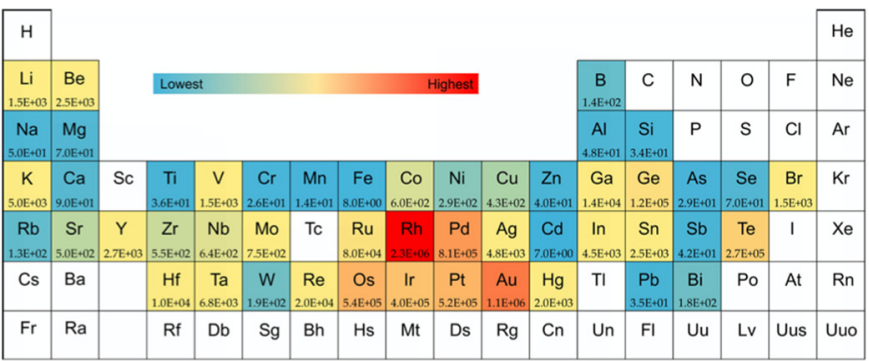

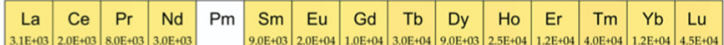

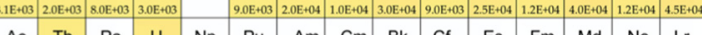

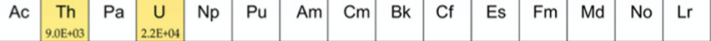

Fig. 18. TMR in 2015 of mineral elements involved in the energy transition.

Neolithic brought a scale change in the need for energy. The energy of water was harnessed, either to provide mechanical work or to ensure irrigation of fields ${ }^{26}$. But most of the energy need was provided by hand labor and by draft animals. Soon, when powerful States like the Greek cities or the Roman Empire were in place, hand labor was provided by slavery: wars became a tool for establishing political power but also for ensuring access to cheap energy, as prisoners of war were enslaved. Note that slavery as an energy resource has been used until the 19th century, with large parts of the African people being displaced across Africa, to Arabia and then to America [77].

Mechanical devices were used in the Middle Ages to harness the energy of rivers (water wheels) and that of the wind (wind mills), i.e. the energy of the Earth gravitational field. Note that wind was used very early (Kuwait, 5500 BCE, Egypt, 330 BCE) to power sailboats. In parallel, heat was used to smelt metals in sophisticated reactors (bloomery) but also to cook and to heat buildings, based on

\footnotetext{
$\overline{26}$ And eventually (Rome) to bring water to fairly large cities.
}

biomass, either wood or charcoal. But work and heat were used separately with the strongest effort being related to work and particularly to hand labor.

The first combination of heat and work was the invention of the steam engine, attributed to Denis Papin and James Watt. Energy resources started to include earth coal and therefore coke and two centuries later, oil and natural gas. Then Hot Air Balloons and the Internal Combustion Engine followed. New energy forms were discovered, related to the electromagnetic force and to the weak and strong interactions, which led in particular to Nuclear Power, fission and fusion. By then energy had several forms, which could be converted one into the other. But some conversions were easy and others more difficult, because of the existence of entropy, i.e. of the quality of energy: work can easily be converted into heat, but not the other way round.

Note that the availability of such a large set of energy forms happened in parallel with the refining of the definition of the concept energy. This is a story told from Europe. In China, coal oil and gas were known BCE, small hot air balloons as well, and therefore the parallel development of science and technology did not happen there as it did in Europe.

Some historians [9], however, disagree with the storyline of one energy type replacing an older one and therefore are refusing the concept of energy transition. They insist on the fact that a new form of energy increases the cocktail of possible energy forms but does not push an older one out of the mix. Incidentally, the same is true of materials [78]. The expression of energy transition has been used for centuries, though!

Reference [9] gives many examples of the resistance of allegedly "old" vs. "new" energy forms: wind mills in the North of France (Lille) were used to make vegetable oil for a long time (50years) in the 19th century before steam engines took over the task; candles and oil lamps, which were supposed to be replaced for lighting by city gas resisted for decades in the 19th century, thanks to 
FRANCE Domestic electricity generation (MW)

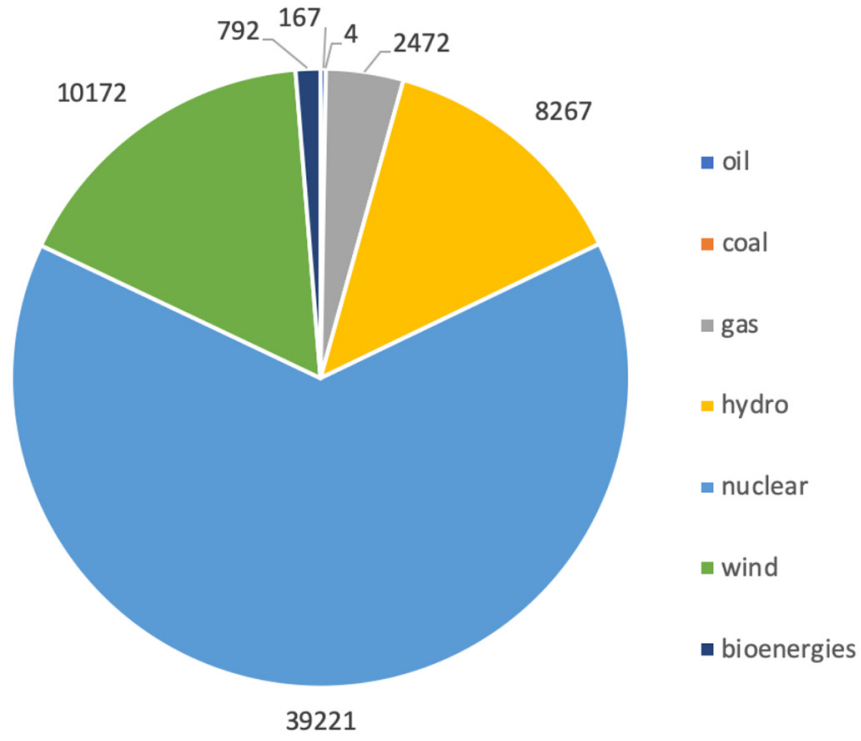

Fig. 19. The grid mix in France on 30 March 2020: $19 \%$ of the power was exported [79].

science-based creative solutions; at the same period, charcoal-based hot metal production resisted also against coke-based ironmaking; in the 20th century, an original renewable energy technology based for example on recovering the energy of tides that developed briskly following the 1st world war, was replaced by oil-fired power plants, the exact opposite of what the present energy transition proposes, etc.

Others would call this "a degree of collective amnesia".

The authors pushed their analysis further by saying that the present Energy Transition is no different from its former avatars: speaking of transition in this case is a hyperbolic way of depicting a change that is not and will not be as radical as claimed. If one looks at the recent past, it is clear that all energy transitions ended up proposing a particular energy mix, with more or less the same ingredients everywhere in different proportions.

They also point out that this transition is hyped as progress with a fascination for innovation, an exaggeration that we called techno-optimism before.

The example of France, where an actual transition took place when it went overwhelmingly to nuclear under President Pompidou, is shown in Figure 19 for a particular day and time. Beyond consumption on the grid, $11.5 \mathrm{GW}$ of power were exported on that day and $510 \mathrm{MW}$ were pumped in PHES devices. However, the pie does not exhibit a sharp transition today, with only $64 \%$ of NP: in the early $2000 \mathrm{~s}$, NP accounted for $80 \%$ of the grid mix: since then, the share of NP was replaced by wind.

Figure 20 shows the case of Norway, where domestic generation is $98 \%$ renewable energy: however, it represents only slightly more than half of domestic consumption, which relies on a large share of imports, with a renewable content less than Norway's. As far as consumption rather than generation is concerned, the transition is not sharp either. Incidentally, one may also note that Norway exports gas and oil and therefore future $\mathrm{CO}_{2}$ emissions along with them [80].
This supports the conclusion of F. Jarrige and A. Vrignon [9]. In the longer term, 2050 and beyond, the commitments taken so far in Europe seem to be projecting a sharper transition, at least as far as the grid mix is concerned.

The point that historians make is illustrated in Figure 21. The transition lasts for longer or shorter periods of time. Also, the function is not monotonous but has its ups and downs. This is inherent in their culture and on the attention they pay to "mechanisms", warry as they are of simplistic models!

\subsection{SSH approaches to Energy Transitions}

There is a lively stream of research conducted by SSH researchers about energy [82-84].

Approaches are of 3 kinds, which are not exclusive of each other:

- SSH offering "help" at the margin to on-going programs, i.e. in the operationalization of selected transition paths; often, however, there is no SSH input in the definition of the strategy of the programs.

- SSH proposing high-level analysis of what the Energy Transition is about from the standpoints of social science [85]: a number of Energy-SSH approaches was thus developed, with a broad diversity as SSH covers many disciplines with different flavors depending on the country ${ }^{27}$.

- SSH looking for an original way to position itself in the strategic thinking and decision making about Energy Transition, with the ambition of delivering recommendations to policy makers independently of the mainstream STEM (Science, Technology, Engineering and Mathematics) approach [82,86,87]. Energy-SSH in Europe has been engaged in intensive lobbying with the EC in order to get included in research calls alongside STEM researchers.

An example of the first approach is the work related to the social acceptability of technologies such as wind turbines, carbon capture and storage or others $[88,89]$. The point is to propose solutions to help shoe in technologies that elicit doubt from the public with appropriate "social engineering techniques". Social scientists appear as guest speakers in meetings populated by technologists and economists.

The second approach reformulates the rationale of the Energy Transition using the concepts and vocabulary of SSH. It reflects on the fact that political power and energy are tightly related, either in the form of an autocratic control or of a democratic approach. Given the ambition of the Energy Transition, it states that the social dynamics of energy transformations should be taken on board, not just technical aspects.

$\overline{27}$ For example, Humanities in France will include literary criticism, which does not seem to be the case in English speaking countries. Similarly, History is considered there as part of Humanities and therefore of SH, which is not the case in France, where the discipline enjoys a separate status, half way between hard and soft sciences. The case of Geography is even more complex! And what about Philosophy? 
NORWAY Annual consumption of electricity (TWh)

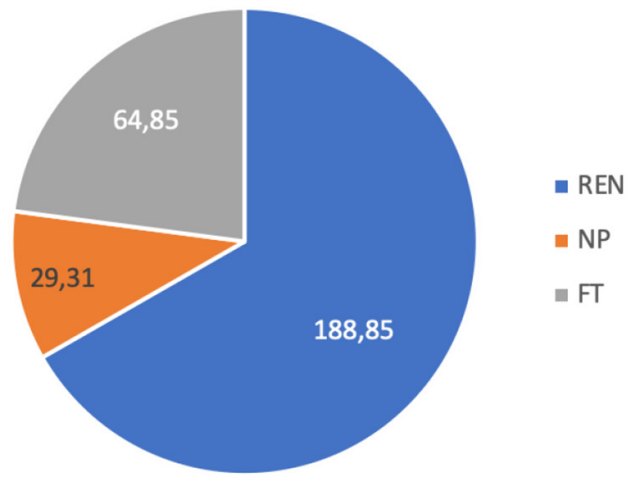

NORWAY Domestic generation of electricty (TWh)

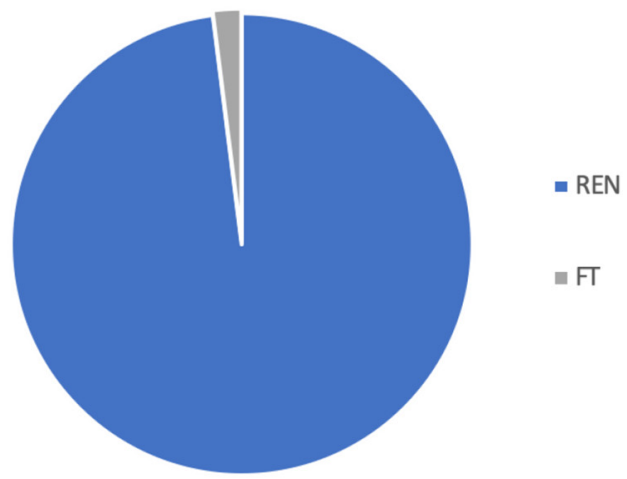

Fig. 20. The grid mix in Norway: domestic generation right and consumption left (2017) [81].

\section{Transition}
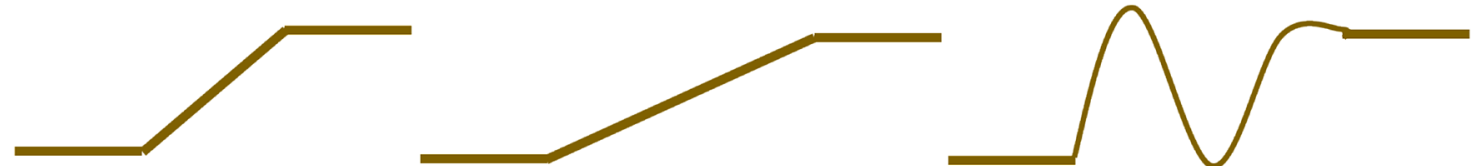

Time

Fig. 21. Transitions: how long do they take? How monotonous are they?

A lot of interesting, thought-provoking points are made-put together below as quotes from [85]:

- "Energy means power and as such implies an asymmetrical structured agency" - which means that the messages of the mainstream STEM reports are one-sided and tainted with techno-optimism due to "entrenched structurings of Modernity".

- "Few themes are more prolifically invoked than energy, as grounds for reductive determinism or essentialist reification".

- "To be substantive (effective), communication should refrain from rhetorical claims at transformation".

- "Cumulative infrastructure developments are often as formative in their effects as wholesale substitution" ${ }^{\prime 28}$.

- "Empower the audacity of this ontological novelty" embedded in the Transition as a better communication style than simply deploring social rejection of some technologies - simply put, avoid intellectual hubris.

- "Contemporary systems for global energy provision" are arguably most implicated at the grandest of scales in "fueling capitalism".

28 Cf. the previous discussions about the intensity of the Transition.
- "The language of entropy, ambitious efforts at energybased social explanations are widespread in anthropology, archaeology, economics, agronomics, industrial and social ecology, sociology, management, politics, the arts, history and futurology".

- "Technical advance.../... tends to be defined in specific 'sectors', tautologously and teleologically by reference to those particular configurations that happen to arise".

- "The potent singularity of this 'one-track' 'race-to-thefuture' 'Enlightenment' imagination, is itself arguably one of the prime forces in this entrenchment. In other words, the magnitude of the fallacy exerts a selfreinforcing effect".

- "In many countries... /... nuclear prowess became intensely associated with national identity".

- "Problems of radioactive waste management, nuclear weapons persistence and proliferation, chronic uncompetitiveness and periodic catastrophic accidents all remain obstinately unresolved" in connection with nuclear power.

- "Whatever the balance of strategy and contingency, it is clear that tactical narratives around a prospective global 'nuclear renaissance' are significantly reinforced" by incumbent interests. 
- "Repeated detailed assessments show that the energy service needs of a more heavily populated and equitable world enjoying radically higher levels of wellbeing, can be cost-effectively met entirely and solely through diverse currently available technological and organizational innovations around wind, solar, biomass, hydro, ocean and geothermal power".

- "As with other essentially political ends in plural societies, it is equally possible legitimately to propound (or contest) either a renewable or nuclear-based global energy vision".

- "Authoritatively asserted 'scientific' knowledges can have the effect of asymmetrically emphasizing particular favored pathways at the expense of others".

- "Risk assessment, cost benefit analysis, life cycle assessment, multi-criteria appraisal and decision theory, are all seriously compromised by their own deepest understandings of their intrinsic policy limitations. The point is not that these methods are somehow entirely without value".

- "When claims are made in energy debates (as elsewhere) to a single exclusively definitive 'evidence based' decision, they are (ironically and by exactly this claim) as plainly wrong as it is possible to be".

- "Challenges of social choice [like the matter of energy transition] are inherently matters for explicitly political - rather than purely analytical - resolution".

- "General governance processes around "Sustainability transitions', for instance, often display a degree of collective amnesia over the active forms of counter-power that made such radical aspirations a possibility in the first place".

- "Explicitly or implicitly-much social science work around energy".

- "The complex breadth of 'Sustainability' - canonically highlighted by the Brundtland Commission around social equity, human and wider ecological integritytends to contract to a single 'low carbon transition' alone" in the present Ecological Transition meaning.

- "Much social research for policy analysis in this [Energy Transition] field, restricts experimentation in 'public engagement' to the securing of instrumental forms of closure".

- "A key problem lies in the powerful general pressures that can act to suppress serious discussion of these wider and deeper issues and forces".

- "We should stress to recognize how knowledge is shaped by power".

- "The role for aspiringly transformative social research on energy lies not in seeking to court the patronage of proximate power, by 'seeing like a state'. The analogy is perhaps more with the dynamics of social movements".

- "Social research also assists in framing priorities, questions and options for these other disciplines-in turn informing its own driving aims and those of society more widely".

- "Social Science.../... should convey to policy making and wider political debates an explicit and symmetrical plurality of social interpretations of energy alternatives, each equally valid under different reasonable perspectives-carefully explicating with each, its associated constituting conditions".

- "Resist the shaping of knowledge by incumbent interests!".

As SSH and STEM cultures are so different, reading each other's papers is complex due to disciplinary vocabulary and style-the so-called silo effect! For example: of utmost relevance, issues raised by $\mathrm{SSH}$ are the "relations between agency and structure; the shaping of knowledges and normativities and the interplay of power, contingency and practice" [85].

The third approach is declined in the EU in the Englishspeaking community [90], in France [82], etc. It constitutes a pro domo argument that is believable but not entirely convincing.

- [91] proposed an analysis of a series of past European projects that shows that Energy Transition topics are run mostly by STEM people and that this would leave a wide berth for $\mathrm{SSH}$ people to step in for the benefit of a different approach beneficial to society. They highlighted two interrelated stories concerning the role of people in low-carbon energy transitions, illustrated with an example on demand-side management, and pointed towards future energy-SSH research and policy priorities.

- [82] proposes a roadmap for the French SSH community to structure itself and catch up with what was accomplished in the English-speaking world. The message is similar: SSH are the only way to propose "open futures"

Finally, the effort of energy-SSH seems to have born fruits, since an on-going Call for proposals from the H2020 program of the European Commission is centered on this topic [91]. It focuses on three items, which are emblematic of issues raised in Europe by the Energy Transition:

- Social innovation (SI) in the energy sector (gives examples of successful social innovation in the energy sector; how can it be encouraged? is SI improving livelihoods and creating business opportunities in the energy sector? does SI lead to more secure energy systems? does it lead to better social acceptance of lowcarbon energy systems?).

- Challenges facing carbon-intensive regions (relationship between coal-intensive regions and livelihoods and the sustainability of the region, which regions cope or don't cope and why? is demography locally dropping? Connection with the development of populism and anti-democratic attitudes).

- Energy citizenship-EC (scale, culture of the groups driving the transition, role of digitization in consolidating EC, connection between EC and achievement of ambitious climate goals).

- Philosophy, particularly the Philosophy of Technology (PoT), also throws more light on these concepts, but the field is too nascent to deserve being reviewed here [92].

\footnotetext{
29 «Les SHS ne peuvent se borner à opérationnaliser une voie de transition et doivent "garder les futurs ouverts". "Il n'y aura pas de profondes transformations dans ce secteur sans ces nouvelles forces vives."》
} 


\section{Conclusions}

The Energy Transition is a powerful narrative meant to propose a direction in which society as a whole is heading, driven as it is by the evolution of its energy mix. It is an aspirational target defined by soft laws in many countries as well as a set of solutions prepared by energy experts of the STEM-energy community to reach this target. Like Sustainable Development, it serves as a moral compass but also as a roadmap that ought to be followed: while the former is now associated with rhetorical change, the latter proposes an agenda for transformative change. Energy issues are momentous and they control the geostrategy of resources at world scale.

The theme of energy transition is not new, either in the long time of History or in the recent past. For example, the two oil shocks of the 1970s caused a transition based on a systematic search for energy efficiency and the strict control of the energy bill. Nowadays, the rationale for the Energy Transition depends on each country: the US wanted energy independence and they got it by opening up non-conventional fossil fuel fields; Germany popularized the Energiewende, with the objective of increasing the share of renewables in the grid, decreasing that of coal and oil-fired power plants and shutting down nuclear power altogether and fast; the other European countries customdesigned their own mix; Japan continued to rely on nuclear power but emphasized safety more. Everyone had also in mind to create a green economic recovery, to launch a durable green growth and to help control Climate Change.

This diversity of meaning and content of the Energy Transition shows that it is hardly an energy transition at all but rather a practical way to implement transformative change in the face of the threat of Climate Change, based on local or national solutions. Rather than an Energy Transition, it would more aptly be called an Ecological Transition.

The expression Transition has been associated with many other qualifiers, for example the Digital Transition, also called digitalization or the 3rd industrial revolution or Industrie 4.0, the Nutrition Transition or the Epidemiological Transition. None of these are in essence connected with the Energy Transition. It is a Western cultural trait to paint everything as being dynamic and driven by change, important but manageable change. Progress, another cliché, tells the same kind of story. At this point, the transformative dimension of Transition has become largely rhetorical.

Beyond the usual storytelling of the STM-energy community, a new narrative is taking shape, carried by the SSH-energy community and associated disciplines. They insist on the fact that the mainstream STEM approach is too narrow-minded and may be bridled by a priori visions, reflecting situations of power in the energy sector: the diversity of meanings of the Energy Transition in various countries is probably in part due to that! Historians also express doubts regarding the existence of energy transitions at all, today or in the past: they give convincing examples of Transitions going in the wrong direction and being delayed almost indefinitely! In addition to being composite in their goals, the Transitions are neither monotonous nor short, which does not eliminate the concept but gives it much flexibility. The difficulties met by some emblematic energy files vis à vis the civil society, like the closure or not of a nuclear power plant, the construction of a nuclear waste storage site or the erection of a dam, could have been avoided if SSH had been on board earlier or at all.

The modern view of thermodynamics is that the central concept in the discipline is entropy not energy [93]. A weaker statement of this is that exergy is more important than energy.

What can this say regarding the Energy Transition? Solar energy is pure exergy and so is the electricity produced by photovoltaic devices. Wind Power derives from gravitational energy, which is also pure exergy. On the other hand, fossil fuels, coal, oil or gas are rarely used as pure exergy as they need to be combusted to be turned into ordinary energy: gasoline is burned in an IC engine to produce mechanical work, oil is burned in a boiler to produce steam and then electricity, etc. There are exceptions like the carbon used in an iron blast furnace, where a major part of the energy used is chemical energy, thus pure exergy; the same is true of many processes in the metallurgical and chemical industries.

Therefore, the Energy Transition calls on high-exergy content energy to replace low-exergy content energy.

This is a bit of a rhetorical comment if one confronts it to the fact that renewables are either based on "lowdensity" fundamental forces (gravity) or demonstrate a low energy efficiency (photovoltaics), with one consequence that the corresponding power plants need more steel, more copper and more concrete.

Note, however, that the "best" solar energy conversion device, photosynthesis, is even less efficient than photovoltaics. Which shows that the process was not designed by engineers or that the concept of energy-efficiency is not a prime driver of the mechanisms that pull biological processes.

\section{Glossary}

3 E's Energy Security, Economic Efficiency and Environmental Protection

ADEME Agence de l'Environnement et de la Maîtrise de l'Énergie, French Energy Agency (France)

AI Artificial Intelligence

CC Climate Change

CCS Carbon Capture and Storage

DLR Deutsches Zentrum für Luft- und Raumfahrt (Germany)

EC European Commission

EC Energy Citizenship

ECE Energy Critical Elements

EcT Ecological Transition

EECCA Eastern Europe, Caucasus, and Central Asia

EnT Energy Transition

ET Energy Transition 


$\begin{array}{ll}\text { ETUI } & \text { European Trade Union Institute } \\ \text { ETUC } & \text { European Trade Union Confederation } \\ \text { EU } & \text { European Union } \\ \text { FC } & \text { Fuel Cell } \\ \text { FT } & \text { Fossil Thermal } \\ \text { GHG } & \text { Greenhouse Gas } \\ \text { ICE } & \text { Internal Combustion Engine } \\ \text { IEA } & \text { International Energy Agency } \\ \text { IER } & \text { Institute for Energy Research (USA) } \\ \text { IJTIS } & \text { International Journal of Transitions and Inno- } \\ & \text { vation Systems } \\ \text { IoT } & \text { Internet of Things } \\ \text { IRENA } & \text { International Renewable Energy Agency } \\ \text { IUPAC } & \text { International Union of Pure and Applied } \\ & \text { Chemistry } \\ \text { METI } & \text { Ministry of Economy, Trade and Industry } \\ & \text { (Japan) } \\ \text { NP } & \text { Nuclear Power } \\ \text { NPP } & \text { Nuclear Power Plant } \\ \text { OECD } & \text { Organization of Economic Cooperation and } \\ & \text { Development } \\ \text { PHES } & \text { Pumped hydroelectric energy storage (STEP in } \\ & \text { French) } \\ \text { POT } & \text { Philosophy of Technology } \\ \text { REmap } & \text { Name of future scenarios developed by IRENA } \\ \text { SDG } & \text { Sustainability Development Goals } \\ \text { SI } & \text { Social innovation } \\ \text { SNBC } & \text { Stratégie Nationale Bas Carbone (France) } \\ \text { SSH } & \text { Social Sciences and Humanities } \\ \text { STEM } & \text { Science, Technology, Engineering and Mathe- } \\ & \text { matics } \\ \text { STIM } & \text { Science, Technologie, Ingénierie et Mathéma- } \\ & \text { tiques } \\ \text { TCEP } & \text { Tracking Clean Energy Progress (IEA) } \\ \text { TMR } & \text { Total Materials Requirement } \\ \text { TPES } & \text { Total Primary Energy Supply } \\ \text { TFEC } & \text { Total Final Energy Consumption } \\ \text { TWH } & \text { Thermodynamic water heater } \\ \text { UN } & \text { United Nations } \\ \text { UNECE } & \text { United Nations Economic Commission for } \\ & \text { Europe } \\ \text { UNEP } & \text { United Nations Environmental Program } \\ & \end{array}$

\section{References}

1. UN Sustainable Development Goals, United Nations, https://sustainabledevelopment.un.org/?menu=1300

2. Die Deutsche Nachhaltigkeitsstrategie, https://www. deutschland.de/de/topic/umwelt/deutsche-nachhaltigkeits strategie-nationale-und-globale-ziele

3. Time for more integrated action with urgency, cohesion and high ambition, WWF Europe, https://wwf.panda.org/knowl edge_hub/sustainable_development_goals/

4. Sustainability, Sustainable development is at the heart of our purpose: Inventing smarter steels for a better world, ArcelorMittal, https://corporate.arcelormittal.com/sustainability

5. J.-P. Birat, Introduction: Man and Nature, Chapter 1, Sustain. Mater. Sci. Environ. Metall. 1, 1-36 (2020), EDP sciences, Les Ulis, France, 476 p.
6. S. Vaclav, Energy Transitions: History, Requirements, Prospects, Praeger, 2010, 178 p.

7. G. Leach, The Energy Transition, Energy Policy 20(2), 116 $123(1992)$

8. Energy Transition, Wikipedia, https://en.wikipedia.org/ wiki/Energy_Transition [accessed on 22 March 2020]. The article is emblematic of the misconceptions about historical trends and economic evolutions that are shared by people that do not belong to the Social Science community but tell historical narratives anyway

9. F. Jarrige, A. Vrignon, Face à la puissance, une histoire des énergies alternatives à l'âge industriel, La Découverte, Paris, 2020, $393 \mathrm{p}$.

10. R.-J. Geerts, Philosophical explorations on energy transition, PhD thesis, Wageningen University, Wageningen, NL, 2017, $172 \mathrm{p}$.

11. J. Diamond, Upheaval, how nations cope with crisis and change, Penguin Books, Allen Lane, 2019, 500 p.

12. Article Mutazione, Changement, révolution (pp. 847-849), in: B. Cassin, ed., Vocabulaire européene des philosophies, Seuil-le Robert, Paris, 2004, 1563 p.

13. A. Marie, P. Goutagny, La notion de Transition en géographie, Université de Dijon, 2019, http:/ / histoire-geographie.ac-dijon. fr/spip.php?article970 [accessed on 22/03/2020]

14. https://en.wikipedia.org/wiki/Demographic_transition\#/ media/File:Demographic-TransitionOWID.png

15. Energy Concept for an Environmentally Sound, Reliable and Affordable Energy Supply, Federal Ministry of Economics and Technology (BMWi), Berlin, Germany, 2010

16. The Energy of the Future: Fourth "Energy Transition" Monitoring Report - Summary, Federal Ministry for Economic Affairs and Energy (BMWi), Berlin, Germany, 2015

17. Energiewende, Wikipedia in English, https://en.wikipedia. org/wiki/Energiewende

18. F. Varela, Germany 2020, Energy Policy review, Country Report, IEA, 2020, https://www.iea.org/reports/germany2020 [accessed on 25/03/2020]

19. Germany's Energy Plan Is Leading to Insecure Supply, Institute for Energy Research (IER), 2019

20. M. Gay, Energiewende en Allemagne : le désastre constaté va s'amplifier, Le Monde de l'énergie, 2019

21. Loi de transition énergétique pour la croissance verte, France, adoptée à l'été 2015

22. A. Mason, W. Martindale, A. Heath, S. Chatterjee, French energy transition law - Global investor briefing, UNEP Finance Initiative, IGCC, IIGCC, 2016

23. ADEME 2035-2050, Actualisation du scénario énergieclimat, ADEME, 2017, $44 \mathrm{p}$.

24. Scénario négaWatt 2017-2050, Réussir la transition énergétique en France, 2019, www.negawatt.org/scenario-nega Watt-2017

25. Picture credit, reference [11]

26. http://www.oecd.org/environment/outreach/green-actiontaskforce-mission.htm

27. UNEP, https://www.unenvironment.org/explore-topics/en ergy

28. S. Tagliapietra, G. Zachmann, O. Edenhofer, J.-M. Glachant, P. Linares, A. Loeschel, Policy brief - The European Union energy transition: Key priorities for the next five years, Policy Brief, Issue 1, July 2018, Bruegel, Brussels

29. European Commission, Energy Roadmap 2050, COM(2011) $\mathbf{8 8 5},(2011)$ 
30. European Commission, A policy framework for climate and energy in the period from 2020 to $2030, \mathrm{COM} / 2014 / 015$ final, 2014

31. European Commission, Commission Proposal for a Regulation: European Climate Law, $\operatorname{COM}(2020)$ 80, (2020)

32. A roadmap to 2050, Global energy transformation, IRENA, International Renewable Energy Agency, Abu Dhabi, 2018, $75 \mathrm{p}$.

33. Japan, IEA, Paris, 2019, https://www.iea.org/countries/ japan

34. Japan, 2016 review, Energy Policy of IEA countries, OECDIEA, 2016, $180 \mathrm{p}$.

35. Y. Qi, N. Stern, J. He, et al., China's Peaking Emissions and the Future of Global Climate Policy, in: China's energy in transition Series, Brookings, Tsinghua Center for Public Policy, 2018

36. 能源生产和消费革命战略 (2016-2030), Government of China, 2016, 41 p, http://www.gov.cn/xinwen/2017-04/ 25/5230568/files/286514af354e41578c57ca38d5c4935b.pdf

37. The Ecological Transition Towards Sustainable Development, A new strategy for 2015-2020 French government

38. A.D. Barnosky, et al., Approaching a state shift in Earth's biosphere, Nature 486, 52-58 (2012)

39. V. Dakos, Ecological Transitions: Regime Shifts, Thresholds and Tipping Points, Oxford bibliographies, HAL archives ouvertes, 2019, https:/ / hal.archives-ouvertes.fr/hal-02195008

40. J.W. Bennett, The Ecological Transition: Cultural Anthropology and Human Adaptation, Pergamon Press, New York, 1976, 378 p.

41. European Parliament, Changement climatique : accord sur de nouvelles règles pour déterminer quels investissements sont écologiques, 2019, https://www.europarl.europa.eu/news/fr/ press-room/20191217IPR69202/de-nouvelles-regles-pour-de terminer-quels-investissements-sont-ecologiques

42. P. Robineau (coordinator), From Transition to Transformation - Sustainable and Inclusive Development in Europe and Central Asia, UNECE, New York and Geneva, 2012, 156 p.

43. É. Laurent, P. Pochet, Towards a social-ecological transition - Solidarity in the age of environmental challenge, ETUI, Brussels, 2015, 36 p.

44. W. Kalinowski, A. Lalucq, P. Frémeaux, The Ecological Transition: A User's Guide, A user's guide on reconciling the necessary and the desirable, in: Alternatives économiques, Les petits matins, 2013

45. J.-P. Birat, The environment, from the standpoints of philosophy, social sciences and political activism, Matériaux \& Techniques 107(1), 2019, DOI: 10.1051/mattech/2018067

46. B. Latour, Imaginer les gestes-barrières contre le retour à la production d'avant-crise, AOC-Média, 2020, https://aoc. media/opinion/2020/03/29/imaginer-les-gestes-barrierescontre-le-retour-a-la-production-davant-crise/

47. B. Latour, Interview, France Inter, le 7/9, 2020

48. J.C.J.M. van den Bergh, B. Truffer, G. Kallis, Environmental Innovation and Societal Transitions, Elsevier, 1(1), 1-23 (2011), DOI: 10.1016/j.eist.2011.04.010

49. K.R. Smith, M. Ezzati, How environmental health risks change with development: The Epidemiologic and Environmental Risk Transitions Revisited, Annu. Rev. Environ. Resour. 30, 291-333 (2005)

50. J. Rotmans, R. Kemp, Managing Societal Transitions: Dilemmas and Uncertainties: The Dutch energy case-study, in: Communication to the OECD Workshop on the Benefits of Climate Policy: Improving Information for Policy Makers, OECD, 2003
51. Global Transitions, KeAi Communications Co, 2021

52. Transition Economies: An IMF Perspective on Progress and Prospects, International Monetary Fund, Washington D.C., 2000

53. J. Markard, R. Raven, B. Truffer, Sustainability transitions: An emerging field of research and its prospects, Res. Policy 41(6), 955-967 (2012)

54. The International Journal of Transitions and Innovation Systems (IJTIS), Inderscience, 2021, https://www.inder science.com/jhome.php?jcode=ijtis

55. K.J. Geels, F.W. Kern, J. Markard, A. Wieczorek, F. Alkemade, P. Wells, An agenda for sustainability transitions research: State of the art and future directions, Environ. Innov. Soc. Trans. 2019, DOI: 10.1016/j.eist.2019.01.004

56. M. Beblavý, I. Maselli, M. Veselková (eds), Emerging Megatrends and scenarios in the socio-ecological transitions, Chapter 2 (pp. 14-25), in: Let's get to work! The future of labour in Europe, Vol. 1, CEPS, Brussels, 2014

57. Office of Technology Transitions of the US DOE, https:// www.energy.gov/technologytransitions/downloads/officetechnology-transitions-overview

58. The European Green Deal, Brussels, $\operatorname{COM}(2019)$ 640, 24 (2019)

59. A Farm to Fork strategy, for a fair, healthy and environmentally-friendly food system, $\operatorname{COM}(2020), \mathbf{3 8 1}$, 2020, 19 p, European Commission, Brussels, https://eur-lex. europa.eu/legal-content/EN/TXT/DOC/?uri=CELE $\mathrm{X}: 52020 \mathrm{DC} 0381 \&$ from $=\mathrm{EN}$

60. M.J. Burkea, J.C. Stephens, Political power and renewable energy futures: A critical review, Energy Res. Soc Sci. 35, 78 $93(2018)$

61. Transition-org, https://transition-org.net

62. Pacte pour la transition, https://www.rtes.fr/pacte-pour-latransition-32-mesures-concretes-en-vue-des-elections-munici pales-de- 2020

63. J. Caletrio, Transition studies, in: Mobile Lives Forum, 2015, http://en.forumviesmobiles.org/marks/transition-studies2839

64. STRN, https://transitionsnetwork.org

65. Transition Research Network, http://www.transitionre searchnetwork.org

66. E.T. Hall, M.R. Hall, Guide du comportement dans les affaires internationales, Allemagne, États-Unis, France, Seuil, 1990, 253 p.

67. M.S. Powers, Applying Schlossberg's Transition Theory to Nontraditional Male Drop-outs, University of Nebraska, 2015, https://digitalcommons.unl.edu/cgi/viewcontent.cgi? article $=1019 \&$ context $=$ cehsedaddiss

68. F.W. Geels, Technological transitions as evolutionary reconfiguration processes: A multi-level perspective and a case-study, Res. Policy 31, 1257-1274 (2002)

69. J.-M. Hauteville, Plan climat: l'Allemagne adopte une taxe carbone plus ambitieuse, Le Monde, Paris, France, 2019

70. La valeur de l'action pour le climat - Une valeur tutélaire du carbone pour évaluer les investissements et les politiques publiques, Rapport de la commission présidée par Alain Quinet, France Stratégie, Paris, France, 2019, 127 p.

71. WHO, 9 out of 10 people worldwide breathe polluted air, https://www.who.int/news-room/air-pollution

72. A. Chemin, Réinventer la ville pour combattre les épidémies, Le Monde, Paris, 2020

73. G. Pitron, La guerre des métaux rares, la face cachée de la transition énergétique et numérique, in: Les liens qui libèrent, 2018, 295 p. 
74. Impacts environnementaux de l'éolien français, ADEME, 2015

75. T. Watari, B.C. McLellan, D. Giurco, E. Dominish, E. Yamasue, K. Nansai, Total material requirement for the global energy transition to 2050: A focus on transport and electricity. Resour. Conserv. Recycl. 148, 91-103 (2019)

76. J.-P. Birat, Materials and energy, Chapter 9 (pp. 391-446), Sustain. Mater. Sci. Environ. Metall. 1, (2020), EDP Sciences, Les Ulis, France, 476 p.

77. C. Coquery-Vidrovitch, Petite histoire de l'Afrique, La Découverte/Poche, 2011, 236 p.

78. J.-P. Birat, Chapter 4: Materials comparison: competition or cooperation?, Sustain. Mater. Sci. Environ. Metall. 1, 173227 (2020), EDP Sciences, Les Ulis, France, 476 p.

79. Power generation by energy source, RTE, France, https:// www.rte-france.com/en/eco2mix/eco2mix-mix-energetiqueen

80. J.-P. Birat, A. Carvallo Aceves, Territorial sustainability footprint, Revue de Métallurgie 109, 323-331 (2012)

81. Norwegian Energy Regulatory Authority, Electricity disclosure 2017, 2017, https://www.nve.no/norwegian-energyregulatory-authority/retail-market/electricity-disclosure$2017 /$ ?ref=mainmenu

82. O. Labussière, A. Nadaï, L'énergie des sciences sociales, in: Collection ATHENA, Open Edition Books, 2015, 166 p.

83. Journal Energy Research and Social Science, Elsevier, https://www.journals.elsevier.com/energy-research-and-so cial-science/

84. Sciences Sociales et Transitions Energétiques, in: Colloquium, 28-29 May, 2015, Grenoble, France
85. A. Stirling, Transforming power: Social science and the politics of energy choices, Energy Res. Soc. Sci. 1, 83-95 (2014)

86. C. Foulds, R. Robison, Mobilising the Energy-Related Social Sciences and Humanities, Chapter 1, in: C. Foulds, R. Robison, eds., Advancing Energy Policy, 2018

87. C. Foulds, R. Robison, eds., Advancing Energy Policy Lessons on the Integration of Social Sciences and Humanities, Palgrave Mac Millan, Switzerland, 2018, 193 p.

88. L. Jammes, P. Vervier, T. Lesueur, Social site characterisation \& stakeholder engagement, Global CCS Institute, Australia, 2012, https://www.globalccsinstitute.com/ar chive/hub/publications/119186/social-site-characterisa tion-stakeholder-engagement.pdf

89. L. Jammes, SHS et sous-sol dans la transition énergétique, in: Séminaire: Les sciences humaines et les nouveaux usages du sol et du sous-sol dans la transition énergétique, 7 October 2019, Nancy

90. L. Ingeborgrud, S. Heidenreich, M. Ryghaug, et al., Expanding the scope and implications of energy research: A guide to key themes and concepts from the Social Sciences and Humanities, Energy Res. Soc. Sci. 63, 101398 (2020)

91. Social Sciences and Humanities (SSH) aspects of the Clean-Energy Transition, Call ID: LC-SC3-CC-1- 2018-2019-2020, https://ec. europa.eu/info/funding-tenders/opportunities/portal/screen/ opportunities/topic-details/lc-sc3-cc-1-2018-2019-2020

92. R.-J. Geerts, B. Gremmen, J. Jacobs, G. Ruivenkamp, Towards a philosophy of energy, Scientiae Studia, São Paulo 12, (2014)

93. H.B. Callen, Thermodynamics and an Introduction to Themostatistics, 2nd ed., John Wiley \& Sons, New York, 1985 
Appendix A: Objectives of the French ecological transition policy of 2015.

GOAL 1 Developing sustainable and resilient territories

GOAL 2 Engaging in a circular and low carbon economy

GOAL 3 Preventing and reducing environmental, social and territorial inequalities

GOAL 4 Inventing new economic and financial models

GOAL 5 Supporting the ecological transformation of economic activities

GOAL 6 Guiding knowledge production, research and innovation towards the ecological transition

\section{GOAL 7 Educating, training and raising awareness of the} ecological transition and sustainable development

GOAL 8 Mobilizing stakeholders at all levels

GOAL 9 Promoting sustainable development at European and international levels 


\section{Appendix B: Death rates related to energy production technologies (curtesy: our world in data).}

Death rates from energy production per TWh

Death rates from air pollution and accidents related to energy production, measured in deaths per terawatt hours (TWh)

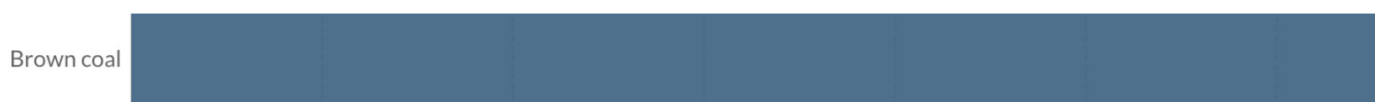

Coal

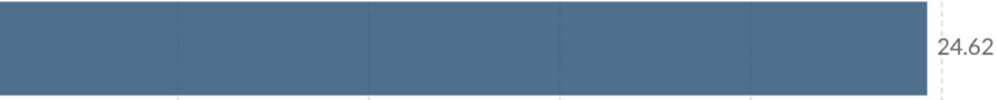

Oil

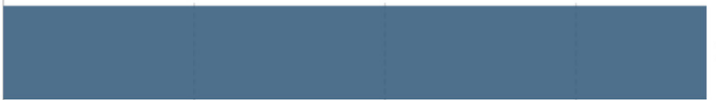

18.43
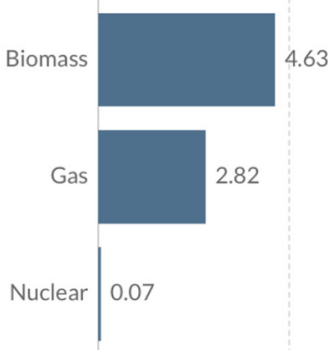

0

5

10

15

20

25

30

Source: Markandya and Wilkinson (2007)

Note: Figures include deaths resulting from accidents in energy production and deaths related to air pollution impacts. Deaths related to air pollution are dominant, typically accounting for greater than $99 \%$ of the total.

Death rates from energy production

Death rates from energy sources is measured as the number of deaths from air pollution and accidents per terawatt-hour (TWh) of energy production.

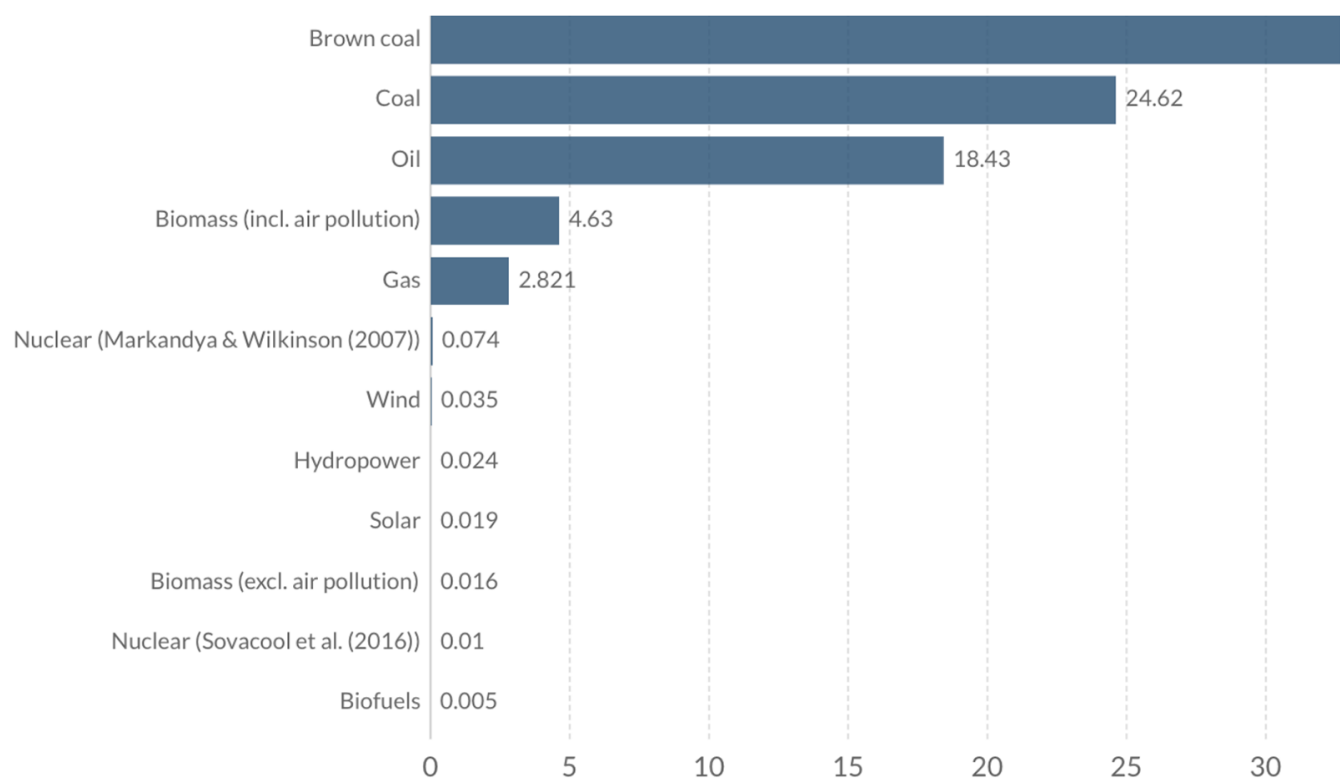

Source: Markandya \& Wilkinson (2007); \& Sovacool et al. (2016)

Cite this article as: Jean-Pierre Birat, How to tell the story of change and transition of the energy, ecological and societal systems, Matériaux \& Techniques 108, 502 (2020) 